\title{
Is Bank Income Diversification Beneficial? Evidence from an Emerging Economy
}

Celine Meslier, Ruth Tacneng ${ }^{*}$, Amine Tarazi

Université de Limoges, LAPE, 5 rue Félix Eboué, BP 3127, 87031 Limoges Cedex, France

\begin{abstract}
:
This paper examines the impact of bank revenue diversification on the performance of banks in an emerging economy. Using a unique dataset with detailed information on noninterest income, our findings show that, conversely to studies on Western economies, a shift towards non-interest activities increases bank profits and risk-adjusted profits particularly when they are more involved in trading in government securities. Our results also indicate that foreign banks benefit more from such a shift than their domestic counterparts. Moreover, we account for the institutional and regulatory environment advocating loans to SMEs and find that higher involvement in non-interest activities is only beneficial for banks with low exposures to SMEs. Our findings have important policy implications in terms of achieving optimal diversification and lower risk exposure, which might conflict with policies aiming to promote SME lending.
\end{abstract}

JEL Classification: G21, G28

Keywords: Emerging economies; Bank Revenue Diversification; Bank Risk and Profitability; Mandated Credit Program

* Corresponding author. Tel: +33 555 149214; fax: +33 555149211.

E-mail addresses: celine.meslier@unilim.fr (C. Meslier), ruth.tacneng@unilim.fr (R. Tacneng) and amine.tarazi@unilim.fr (A. Tarazi) 


\section{Introduction}

Over the last three decades, the financial industry in developed as well as in developing countries has experienced major changes. Deregulation and increased competition has led banks to expand their activities and to develop new lines of businesses beside their traditional interest activities. Banks have diversified their income sources by performing new activities, such as underwriting and trading securities, brokerage and investment banking and other activities, which generate non-interest income. The implications of such changes on bank performance, i.e. profitability and risk, have been broadly addressed in the literature but no consensus has been reached at this stage. Most studies find that non-interest activities are often associated with profitability gains but also higher risk because of their unstable nature. By investigating the US banking industry, Stiroh (2004a and 2004b), Stiroh (2006) and Stiroh and Rumble (2006) find that a higher share of non-interest income positively affects the volatility of bank returns inducing higher risk. Consistent with US studies, Lepetit et al. (2008a) show that banks that are more reliant on non-interest activities exhibit higher default risk than banks which mainly supply loans. This positive link mainly holds for small banks and is essentially driven by commission and fee activities. Specifically, a higher share of trading activities is not associated in their study with higher risk and for small banks it implies, in some cases, lower asset and default risks. Mercieca et al. (2007) find that small European banks do not benefit from diversification. Higher non-interest income shares are associated with lower profitability and increased risk implying lower risk-adjusted profits. Furthermore, they find trading activities to be both risky and unprofitable. Conversely, analyzing Italian banks, Chiorazzo et al. (2008) find that income diversification improves the risk/return tradeoff. Such diversification gains are stronger for large banks.

Whereas the case of developed countries (US and Europe) is well documented in the empirical literature, very few papers focus on emerging countries. In a cross-country study conducted for a sample of listed banks from 11 emerging countries, Sanya and Wolfe (2011) find that diversification between interest and non-interest activities as well as within both types of activities increases profitability and reduces bank insolvency risk. Berger et al. (2010) examine the case of the Chinese banking industry and find evidence of a diversification discount ${ }^{1}$, which is stronger for domestic banks than for foreign banks, suggesting that different ownership structures induce different effects of diversification on bank valuation. Focusing on the Mexican banking system, Maudos and Solis (2009) highlight

\footnotetext{
1 Their diversification discount indicators are profit premiums and cost discounts. They are measured as the difference between the predicted profits (respectively the predicted cost) between the observed diversified bank and a hypothetical quasi-focused bank.
} 
the existence of a negative relationship between banks' interest margin and non-interest income. Their findings are consistent with the results obtained for European banks by Lepetit et al. (2008b) indicating possible cross-subsidization of non-interest activities with traditional intermediation activities where banks use loans as a loss leader.

The objective of this paper is to contribute to the scarce literature dedicated to the impact of diversification on bank profitability and risk in the case of emerging and developing countries. As financial markets are less mature in such countries than in developed countries, banks play a crucial role in the financing of the private sector and specifically for small and medium enterprises (SMEs). As discussed in the Financial Access 2010 Report provided by the IFC, access to finance by SMEs is one of the main policy issues for developing countries and specific regulations encouraging banks to lend to priority sectors, including SMEs, are implemented in some emerging countries like Afghanistan, India, the Philippines and Pakistan. By imposing constraints on bank lending behavior, such regulations may influence how banks may efficiently allocate scarce financial resources. Another important issue for emerging and developing countries is the role of corporate ownership and governance in affecting bank behavior. As reported by De Nicolo and Loukoianova (2007), two main trends in bank ownership structure in emerging countries can be highlighted over the 1993-2004 period. While foreign ownership substantially increased, state-ownership remained stable and still tends to increase in some group of countries. Several papers have investigated the effect of a higher foreign presence in local banking markets. Foreign bank entry is generally found to positively impact competition and, in some cases, improve the efficiency of the local banking system (Claessens et al., 2001; Lensink and Hermes, 2003). However, studies regarding credit availability provide mixed results. While for some authors, foreign bank entry reduces credit constraints (Clarke et al., (2006)), others such as Detragiache et al. (2008) and Gormley (2010) find that foreign bank entry does not necessarily improve access to finance for local firms. Meanwhile, in terms of government ownership of banks, an abundant theoretical literature stresses its negative effect in terms of efficiency and risk (Shleifer, 1998; Shleifer and Vishny, 1998).

In order to assess the bank diversification/profitability and risk nexus in emerging economies, we focus on the case of the Philippines. Focusing on a single country enables us to analyze the effects of diversification within a uniform environment and extend the paper of Sanya and Wolfe (2011) by going deeper into the investigation, using a detailed breakdown of non-interest income of Philippine banks. Specifically, our data allow us to distinguish traditional from non-traditional sources of non-interest income, which may have different 
effects on bank performance. We also take into account banks' ownership type in assessing bank profitability and risk as the Philippine banking system has experienced foreign bank entry after the financial liberalization in the early 90 s and is also characterized by the presence of some state-owned banks. Furthermore, we consider a specific regulation on Philippine banks, which is also implemented in several emerging economies. Philippine banks are required to set aside at least $6 \%$ and $2 \%$ of their loan portfolio to small and medium enterprises, respectively. Other ways to comply, however, are present, which include the purchase of government notes, securities and negotiable instruments offered by the Small Business Guarantee and Finance Corporation (SBGFC) ${ }^{2}$. These may be the best alternatives, especially for banks that have underdeveloped lending technologies in financing small businesses. To our knowledge, this is the first study of bank diversification in an emerging economy that looks into this regulatory aspect ${ }^{3}$. This question is of particular interest for emerging countries where small business lending is a crucial issue. Our study does not aim to provide a direct assessment of the effect of such SME financing regulation on bank diversification behavior as data on individual bank loan portfolio disaggregated according to the size of borrowing firms are not available. Nevertheless, it provides insights on the impact of mandated credit programs to SMEs on the benefits or drawbacks of an increase in bank income diversification in terms of profitability and risk.

We conduct our empirical investigation over the 1999-2005 period using a sample of 39 universal and commercial banks in the Philippines with a very detailed breakdown of annual data on income structure provided by the Central Bank of the Philippines. This allows us to deeply analyze bank diversification behavior by examining the effect on profitability and risk not only of the main components of non-interest income (fee-based, trading and other noninterest income) but also by considering a detailed categorization of such components. Estimations are also conducted according to bank ownership profiles that may cause divergence in the diversification-profit/risk relation. In extension, we also examine the effect of income diversification for a specific category of banks in the Philippines, universal banks, whose additional functions include engagement in the underwriting of securities of other corporations ${ }^{4}$.

Our results indicate that income diversification and a shift towards non-interest income has a positive influence on the profitability and risk-adjusted profitability of Philippine banks.

\footnotetext{
2 Republic Act No. 6977, Section 13. Mandatory Allocation of Credit Resources of Small and Medium Enterprises.

${ }^{3}$ Wolfe and Sanya (2011) find that a higher banking freedom and better investor protection are associated with higher profitability. However, they do not explicitly explore the effect of such regulations on the risk implications of increased bank diversification.

${ }^{4}$ Republic Act 8791; Presidential Decree No. 129.!
} 
The impact, however, is stronger for foreign banks than domestic banks. Moreover, we find that the gains from income diversification are mainly derived from an increase in the involvement in non-traditional, non-interest generating activities of banks, such as trading securities. We attribute our results, which are in contrast with the findings of several US banking studies to differences in terms of income structure. Ninety percent of fee-based income in the Philippines is considered traditional, and fee-based income growth is strongly correlated with net interest income. On the other hand, trading income comprises almost half of non-interest income, compared with less than $10 \%$ in US banks. Standard portfolio theory predicts that, a shift towards trading activities, which are the least correlated with traditional intermediation activities, would lead to larger benefits from diversification. In contrast with what is observed in the US, we do not find evidence that trading income's volatility cancels out its positive impact on profitability. Overall, our main result is consistent with Sanya and Wolfe (2011), who find revenue diversification to be beneficial for emerging economies.

Our findings also show that banks that are lending less to SMEs are the beneficiaries of increased profits from a shift towards non-interest activities, implying possible high switching costs from lending to non-lending activities for banks that specialize in relationship lending. Banks, which are in a better position to diversify their income portfolio away from interestgenerating activities, are more likely to alternatively comply with the mandated credit program (i.e. through the purchase of SBGCF liability instruments). For these banks, reallocating resources away from profitable non-interest income generating activities to the less familiar SME market may be very costly, which may discourage compliance by directly lending to SMEs. Finally, we also investigate a subsample of universal banks and find that higher involvement in investment house activities is associated with higher risk.

The remainder of the paper is organized as follows. Section 2 discusses the data and variables used in our study and presents recent trends in the income structure of the Philippine banking industry. Section 3 describes the hypotheses tested, the method and the econometric specifications. Section 4 provides the results of our estimations while section 5 goes deeper by investigating further issues. Section 6 presents the robustness checks and Section 7 summarizes the findings and concludes the paper.

\section{Data and Variables, Descriptive Statistics and Trends in the Philippine Banking Industry}

The nature and structure of banks in emerging economies has been changing in the past decades because of several factors. Hawkins and Mihaljek (2001) cites four global forces of 
change responsible for shaping the emerging economies' banking industries - technological innovation, deregulation of financial services, changes in corporate behavior and the crises that struck Asia and Latin America in the 90s.

The introduction of universal banking in 1980 and the financial liberalization that opened up the economy to international competition have paved way to the changes in the way Philippine banks do business. Growing competition over the period in the Philippine banking market has provided incentives for commercial banks to diversify their activities and to increase the share of non-interest activities (Gochoco-Bautista (1999)). Banks have been providing a broader array of financial services, which include not only the extension of loans but also underwriting and distributing securities, sale of investments, online banking and commission and fee activities ${ }^{5}$. In the Philippines, banks are classified in six main categories ${ }^{6}$ : universal banks, commercial banks, thrift and savings banks, rural banks, cooperative banks and Islamic banks. In 2005, universal and commercial banks alone comprise 89.29\%, 89.47\% and $90 \%{ }^{7}$ of the total assets, deposit liabilities and loans and investments outstanding, respectively of the entire Philippine banking system. Universal banks have the authority to exercise, in addition to the functions authorized for a commercial bank ${ }^{8}$, the powers of an investment house ${ }^{9}$. These figures show that universal and commercial banks are the primary lenders to both households and institutions in the country. Their behavior generally shapes that of the banking system and impacts the economy.

\subsection{Data Collection and Sample Selection}

The sample used in this study includes 39 universal and commercial banks in the Philippines from 1999 to 2005 . The amendment ${ }^{10}$ of the manual of accounts and the Central Bank's reportorial requirements for banks implemented in 2006 does not allow us to have the same income categorizations after 2006. We construct our sample using two criteria: (1) banks must have at least data for three years and, (2) the gross income components must be

\footnotetext{
${ }^{5}$ Over the past twenty years, non-interest income has grown over $700 \%$ (200\% more than the growth rate in interest income).

6 The General Banking Law of 2000 (Republic Act No. 8791).

7 Author's computations from the Banking Statistics published in the Bangko Sentral ng Pilipinas website.

${ }^{8}$ Article II- Operations of Commercial Banks (Republic Act No.8791). A commercial bank shall have, in addition to the general powers incident to corporations, all such powers as may be necessary to carry on the business of commercial banking, such as accepting drafts and issuing letters of credit; discounting and negotiating pormissory notes, drafts, bills of exchange, and other evidence of debt; accepting or creating demand deposits; receiving other types of deposits and deposit substitutes; buying and selling foreing exchange and gold or silver bullion; acquiring marketable bonds and other debt securities; and extending credit, subject to such rules as the Monetary Board may promulgate.

${ }^{9}$ From the Omnibus Rules and Regulations for Investment Houses and Universal banks registered as underwriters of securities, an investment house is defined as any enterprise which primarily engages, whether regularly or on an isolated basis, in underwriting securities of another person or enterprise, including securities of the Government or its instrumentalities.

${ }^{10}$ Circular No. 512. Amendment of the Manual of Accounts and BSP Reportorial Requirements for Banks. The Financial Reporting Package (FRP) is designed to align the Manual of Accounts and the BSP Reportorial requirements with the provisions of the Philippine Financial Reporting Standards (PFRS) and Philippine Accounting Standards (PAS). The new BSP reportorial requirements shall become effective starting with the 31 December 2006 month-end/quarter-end reports.
} 
non-negative. The first criterion is set to confine the panel regressions on banks with sufficient number of observations. Meanwhile, the second criterion ensures that the diversification measures, particularly the indices and income shares are bounded from 0 to 1 . We also apply several measures to check the presence of outliers and influential observations ${ }^{11}$. We also exclude banks that were merged and/or were acquired during the period $^{12}$. We hence end up with an unbalanced panel consisting of 39 banks and 218 observations.

Our sample of banks represents $86.81 \%^{13}$ of the Philippine banking system and $96.3 \%$ of the universal and commercial banking system in terms of total assets ${ }^{14}$.

The whole sample consists of 23 domestic and 16 foreign banks ${ }^{15}$, and 16 listed and 23 non-listed entities. In terms of asset size, we identify 8 large banks (Average Asset > 140 billion pesos), 13 medium-sized (30 billion pesos < Average Asset $<120$ billion pesos) and 18 small ones (Average Asset $<30$ billion pesos). Bank classifications in terms of size are defined from an examination of the distribution of banks both in terms of their average assets over the period of the study and bank asset distribution by their yearly amounts. We note that most of the smaller banks in the sample are foreign-owned, branches or subsidiaries of foreign banks and that the largest banks are dominantly domestic banks. Among the 8 large banks, 2 are government banks. Excluding the state banks, our sample of domestic banks is composed of 12 universal banks and 9 commercial banks.

Balance sheet and net income information are obtained from the Data Center of the Bangko Sentral ng Pilipinas and its website on an annual basis ${ }^{16}$. Our dataset provides us a detailed breakdown of operating income and its components. This enables us to carry out an in depth study on non-interest income, its main components - fee-based, trading and other non-interest income, and their respective disaggregation. Fee-based and trading activities include respectively, bank commissions, service charges/fees and other commissions and

\footnotetext{
${ }^{11}$ Aside from graphically looking at box plots and scatter plots to identify outliers, we confirm these outliers by computing the DFBETA and leverage measures after the estimations. The DFBETA measures the distance that a regression coefficient would shift when an observation is included or excluded from the regression, scaled by the estimated standard error of the coefficient (Baum, 2006).

${ }^{12}$ We exclude banks that were merged and acquired during the period because there are not enough observations for these banks to include in our study.

13 Mean over the period of the study.

14 In 1999, there are a total of 46 universal and commercial banks, and in 2005, 41 universal and commercial banks

${ }^{15}$ Banks are classified as foreign if: 1) they are subsidiaries of foreign banks, or 2) branches of foreign banks. This classification is mainly drawn from the Monetary Board's authorized mode of entry (Sec. 2, Republic Act NO. 7721) of foreign banks to operate in the Philippine banking system. Sec. 2. Modes of Entry - The Monetary Board may authorize foreign banks to operate in the Philippine banking system through any of the following modes of entry: (i) by acquiring, purchasing or owning up to sixty percent (60\%) of the voting stock of an existing bank; (ii) by investing in up to sixty percent $(60 \%)$ of the voting stock of a new banking subsidiary incorporated under the laws of the Philippines; or (iii) by establishing branches with full banking authority: provided, that a foreign bank may avail itself of only one(1) domestic bank of new banking subsidiary. (Republic Act NO. 7721, An Act Liberalizing the Entry and Scope of Operations of Foreign Banks in the Philippines and for other purposes).

${ }^{16}$ www.bsp.gov.ph
} 
income from trading government securities, private equity/debt; financial futures, forwards and swaps; profit from the sale of investments; and profit from foreign exchange.

For the listed banks of our sample, daily market data for stock prices are obtained from Datastream International.

\subsection{Definition of variables}

\subsubsection{Diversification measures}

In this study, two sets of diversification indicators are computed and alternatively used to assess the effect of the increased diversification of Philippine banks on their profitability and risk.

A first set of indicators used in this study consists of ratios which represent the share of non-interest income in total operating income, as well as the shares of each component of non-interest income in total operating income. The variable NII is equal to the percentage share of non-interest income in total operating income, where non-interest income ${ }^{17}$ is the sum of fee-based income, trading income and other non-interest income. We use the gross values because there is no categorical expense attributed to these activities alone in the income statement provided in our data. In addition, the reported non-interest expense is independent of the non-interest income. Our definition of total operating income is consistent with the studies of Stiroh (2004b), Stiroh and Rumble (2006) and Chiorazzo et al. (2008).

In equation, NII is computed as follows:

$N I I=$ Non-interest Income/Total Operating Income

We also disaggregate NII into three components as defined by the Central Bank $F E E^{18}, T R A D$ and $O t h e r$. These variables are computed as follows:

$F E E=$ Fee-based income ${ }^{19} /$ Total Operating Income

$T R A D=$ Trading income ${ }^{20} /$ Total Operating Income

Other $=$ Other income/Total Operating Income

A second set of indicators used in this paper, FOCUSk, consists of Herfindahl indices. As in Chiorazzo et al. (2008), Stiroh and Rumble (2006) and Sanya and Wolfe (2011), the

\footnotetext{
${ }^{17}$ The definition of the non-interest income accounts are shown in the Appendix 1.

18 The definition of the different components of non-interest income are drawn from the Bangko Sentral ng Pilipinas' glossary of terms, which can be found in the BSP website, www.bsp.gov.ph/banking/glossary.asp

${ }^{19}$ Fee-based income $=$ Bank commissions + service charges $/$ fees + other fees $/$ commissions

${ }^{20}$ Trading income $=$ Trading gains/(losses) $($ from government securities, private debt/equity securities, and financial futures, options) + Foreign exchange profits/(losses)+Gold trading gains/(losses) + Profit/(loss) on sale of redemption of investments.
} 
indices measure how focused or specialized a bank is on its income generating activities. We compute them as follows:

Let $\mathrm{X}_{\mathrm{i}, \mathrm{t}}^{\mathrm{j}}$ be the nominal exposure of bank $i$ at time $t$ to activity $j$ where $j=1, \ldots, \mathrm{n} . \mathrm{X}_{\mathrm{i}, \mathrm{t}}^{\mathrm{j}}$ denotes the corresponding relative exposure, i.e.

$$
\begin{array}{r}
\mathrm{x}_{\mathrm{i}, \mathrm{t}}^{\mathrm{j}}=\frac{\mathrm{X}_{\mathrm{i}, \mathrm{t}}^{\mathrm{j}}}{\sum_{i=1}^{n} \mathrm{X}_{\mathrm{i}, \mathrm{t}}^{\mathrm{j}}} \\
\text { FOCUSk }_{\mathrm{i}, \mathrm{t}}^{\mathrm{j}}=\sum_{j=1}^{n}\left(\mathrm{X}_{\mathrm{i}, \mathrm{t}}^{\mathrm{j}}\right)^{2}
\end{array}
$$

where $k=1, \ldots, 4$.

FOCUSk is an index equal to 1 when total income is generated from one source (specialized) and $\frac{1}{\mathrm{n}}$ when exposures to each income component are equal (well-diversified). A lower value of the index indicates that a bank is more diversified. $k$ denotes the level of disaggregation of operating income (FOCUS1), or of non-interest income (FOCUS2) and its components (FOCUS3 and FOCUS4) used to compute the indicator. Our first index, FOCUS1 is based on the disaggregation of the operating income - net interest income and non-interest income. The three other indices we use, FOCUS2, FOCUS3 and FOCUS4 ${ }^{21}$, are based on the disaggregation of non-interest income, fee-based income and trading income, respectively.

\subsubsection{Bank Profitability and Performance Measures}

To measure the profitability of a bank, we use the bank income statement return on average assets $(R O A)$ and construct a risk-adjusted profitability measure, SHROA, following Chiorazzo et al. (2008). We define it as the ratio of ROA for a given year to the standard deviation of ROA over the period of study, 1999-2005.

$$
\mathrm{ROA}_{\mathrm{it}}=\frac{\text { NetIncomeAfterTax }_{\mathrm{it}}}{\left(\left(\text { Asset }_{\mathrm{it}}+\text { Asset }_{\mathrm{it}-1}\right) / 2\right)}
$$

\footnotetext{
${ }^{21}$ FOCUS2 $=(\text { share of interest income to total operating income })^{\wedge} 2+(\text { share of fee-based income to total operating income })^{\wedge} 2+($ share of trading income to total operating income $)^{\wedge} 2+(\text { share of other noninterest income to total operating income })^{\wedge} 2$

FOCUS3 $=(\text { share of interest income to total operating income })^{\wedge} 2+(\text { share of bank commissions to total operating income })^{\wedge} 2+($ share of service charges to total operating income $)^{\wedge} 2+(\text { share of other commissions/fees to total operating income })^{\wedge} 2+($ share of trading income to total operating income $)^{\wedge} 2+(\text { share of other noninterest income to total operating income })^{\wedge} 2$

FOCUS $4=(\text { share of interest income to total operating income })^{\wedge} 2+(\text { share of fee-based income to total operating income })^{\wedge} 2+($ share of trading gain from government securities to total operating income $)^{\wedge} 2+($ share of trading gain from private debt/equity to total operating income $)^{\wedge} 2+(\text { share of trading gain from financial futures to total operating income })^{\wedge} 2+($ share of foreign exchange profit to total operating income $)^{\wedge} 2+(\text { share of profit from sale of redemption of investments to total operating income })^{\wedge} 2+($ share of other non-interest income to total operating income) $)^{\wedge}$
} 


$$
\mathrm{SHROA}_{\mathrm{it}}=\frac{\mathrm{ROA}_{\mathrm{it}}}{\sigma \mathrm{ROA}_{\mathrm{i}}}
$$

\subsubsection{Bank Risk Measures}

For the 16 listed banks in our sample, we compute risk and insolvency measures using market data obtained from DataStream International. There are a total of 16 listed banks in our sample; however, sufficient data are only available for 15 banks. We compute risk-taking measures such as i) the market model beta (Beta $)^{22}$ coefficient estimated through a GARCH model measuring systematic risk, ii) total risk (TotRisk), which is the standard deviation of weekly returns ${ }^{23}$ and iii) specific risk (RiskSpec) ${ }^{24}$, which is the standard deviation of the market model residual. We also compute a default risk measure using a market-data-based Zscore $(M Z)^{25}$. This measure represents the number of standard deviations below the mean by which profits would have to fall to deplete equity capital (Boyd et al. (1993)).

\subsection{Main trends in portfolio structure and income structure in the Philippine banking system}

Tables $1 \mathrm{~A}$ and $1 \mathrm{~B}$ highlight significant differences in income structure according to bank size (large, medium and small), bank type (universal and commercial banks) and ownership type (foreign and domestic).

[Insert Tables 1A and 1B]

Over the 1999-2005 sample period, the share of non-interest income in total operating income is, on average, equal to $35.92 \%$. Most of the non-interest income is drawn from trading activities $(45.30 \%)$ compared to fee-based activities $(38 \%)$. Trading in government securities and foreign exchange profit are the largest source of trading income ${ }^{26}(30.60 \%$ and $51.50 \%$ ), while service charges dominate the fee-based income sources (61.40\%). We can observe different profiles of diversification and non-interest income structure according to the size and ownership structure of the bank. Larger banks present a higher level of non-interest income in total operating income (38.16\% for large banks and 39\% for medium-sized banks)

\footnotetext{
${ }^{22}$ We estimate the single index market model over the period $[t-100, t]$ to calculate the value of the beta at date $t$.

${ }^{23}$ Daily stock prices are used to calculate weekly stock returns. The standard deviation of weekly stock returns at date $t$ is computed over the period $[t-100, t]$.

${ }^{24}$ The single index market model is computed for each trading day over the period $[t-100, t]$. We use the standard deviation of residuals to estimate specific risk at date $t$.

${ }^{25} \mathrm{MZ}=\frac{\overline{\mathrm{R}}+1}{\sigma}$ where $\overline{\mathrm{R}}$ is the mean of the weekly returns $\mathrm{R}_{\mathrm{t}}$ for a given year and $\sigma$ is the standard deviation of weekly returns.

${ }^{26}$ The mean of the different categories of TRAD (GS, PD, FF, PI an A FP) do not necessarily add up to that of TRAD because of the second criterion used to select our sample: the gross income components must be non-negative, which ensures that the focus indices are bounded from 0 to 1 .
} 
than small banks (32.22\%). However, the difference between large and medium-sized banks becomes more pronounced when we exclude state banks. Non-interest income is mainly generated from trading activities across banks of different sizes, with the exception of large banks when state banks are excluded. Foreign exchange profit and trading of government securities are the two main sources of trading income for all types of banks. However, whereas foreign exchange profit represents the main component for large and small banks (38.50\% and $67.60 \%$ ), the trading income of medium-sized banks comes essentially from the trading of government securities $(43.10 \%)$.

In terms of ownership, we observe that the degree of involvement in non-interest activities is similar between domestic banks and foreign banks. For foreign banks, fee-based activities represent the main source of non-interest income $(47.70 \%)$, followed by trading activities (40.80\%). For these banks, foreign exchange profit is the main source of revenue in trading activities $(74.70 \%)$. On the contrary, domestic banks are more involved in trading activities (47.80\%), of which government securities trading is the largest component (41.90\%). Marked differences are also observed between universal and commercial banks. Universal banks have higher shares of non-interest income compared to commercial banks (39.38\% and $34.62 \%)$. In addition, commercial banks have higher shares of fee-based income but universal banks present a higher involvement in trading and other non-interest activities.

Philippine banks exhibit higher levels of involvement in non-interest activities than those reported in Sanya and Wolfe (2011) for their set of emerging countries and similar levels of involvement in non-interest income activities in direct comparison with those reported in US and European studies. We observe differences, however, in terms of the structure of non-interest income. We stress the relatively high involvement in trading activities for Philippine banks. In 2000, Stiroh (2004b) reports that in the case of US banks, an average bank's fees and other income makes up $27 \%$ of net operating income, while only $3.5 \%$ come from trading income. In Europe, Lepetit et al. (2008) show that over the 19962002 period, average commission income comprises $23.16 \%$ of net operating income, and 9.7\% from trading income. Indeed the differences in the income structure of banks across banking markets may contribute to how a shift towards non-interest income may impact bank profits and risk-adjusted profits.

\section{Theoretical Framework, Hypotheses and Models}

The structural changes in the banking industry and the proliferation of alternative financing sources for firms have enabled banks to consistently look out for other ways to 
increase their profits besides lending. From a theoretical point of view, banks benefit from economies of scope when they diversify their income (Klein and Saidenberg, 1997). Banks increase their efficiency and enhance profitability as they tend to eliminate redundant operations and capitalize on obtained client information when they process loans to facilitate provision of other financial services.

Conventional wisdom asserts that revenue diversification, or a shift from interest to non-interest income, should reduce total risk. Activities that generate non-interest income are thought to be negatively, weakly or imperfectly correlated with those that produce interest income, thereby stabilizing profits and improving the risk-return trade-off. In addition, a shift toward non-interest income is believed to reduce cyclical variations of bank profits, depending less on overall business conditions (Stiroh, 2004b).

While it may seem that diversification is largely desirable for a bank, arguments that refute the ability of income diversification to reduce risk are offered in several banking studies. Notably, DeYoung and Roland (2001) offers three ways by which non-interest income may increase bank earnings' volatility. First, the presence of high switching costs for borrowers associated with lending relationships may suggest that banks tend to easily lose clients from a fee-based one. Second, a bank tends to additionally invest in technology and human resources as it moves towards activities that generate noninterest income; hence, increasing operating leverage and thus, earnings volatility. Third, some fee-based activities that may be carried out with little or no regulatory capital could be associated with a high degree of financial leverage, which increases earnings volatility. Financial innovation, such as the increased bank usage of derivative instruments and other financial transactions has also provided various opportunities to leverage a portfolio. New risks are compounded on top of existing risks, potentially offsetting or cancelling out the benefits from diversification.

We thus test the following hypothesis:

Hypothesis 1: A shift towards non-interest income enhances bank profitability and reduces risk, hence improving bank risk-adjusted profits.

\section{Model 1:}

$\mathrm{Y}_{\mathrm{it}}=\alpha_{\mathrm{it}}+\beta_{1} \mathrm{FOCUS1}_{\mathrm{it}}+\beta_{2} \mathrm{NII}_{\mathrm{it}}+\delta \mathrm{Z}_{\mathrm{it}}+\varepsilon_{\mathrm{it}}$

where $Y_{i t}$ is either a measure of profitability, risk-adjusted profitability or risk ; FOCUS $1_{i t}$ is the measure of diversification based on the breakdown of total operating income in two 
components (interest and non-interest income) and $\mathrm{NII}_{i t}$ is the share of non-interest income. $\mathbf{Z}_{\mathrm{it}}$ is a vector of control variables.

$\beta_{1}$ measures the impact of diversification and $\beta_{2}$, the direct effect of a shift from interest activities to non-interest activities. If income diversity leads to higher profits and risk-adjusted profits, one would expect $\beta_{1}$ to be negative.

We follow here the methodology developed by Stiroh and Rumble (2006) in order to assess the effects of diversification towards non-interest activities. The impact of a change in non-interest income on profitability and risk is measured using the first derivative of our dependent variables with respect to non-interest income:

$\left(\frac{\partial \mathrm{Y}_{\mathrm{it}}}{\partial \mathrm{NII}_{\mathrm{it}}}\right)=\beta_{1}{ }^{\prime}\left(\frac{\partial \mathrm{FOCUS}_{\mathrm{it}}}{\partial \mathrm{NII}_{\mathrm{it}}}\right)+\beta_{2}{ }^{\prime}$

The first term on the right-hand side of equation (10) measures the effect of a change in the non-interest income share through its effect on diversification. As in Stiroh and Rumble (2006), we refer to this as the indirect effect of a change in non-interest income. As this effect depends both on the sign of $\beta_{1}$ 'and the magnitude of the non-interest income share, the indirect effect is calculated accordingly for different levels of non-interest income. Meanwhile, $\beta_{2}$ ' captures the direct effect of a shift from interest income to non-interest income. Using a portfolio-style interpretation, $\beta_{1}{ }^{\prime}$ measures the covariance effect, while $\beta_{2}$ ' measures the variance effect.

The net effect, which is the sum of the direct and indirect effects, determines how profitability and risk vary with an increase in the share of non-interest income.

The dependence, however, between $\beta_{1}$ ' and $\beta_{2}$ ' raises econometric issues since NII and FOCUS1 are collinear. Although both estimates may be unbiased, their variance and covariance are overestimated (Chiorazzo et al. 2008). Wald tests need to be conducted to check the joint statistical significance of $\beta_{1}{ }^{\prime}$ and $\beta_{2}$ ' in the various estimations. Moreover, we also estimate the equation by using only NII to check for robustness.

Several empirical research studies argue that the potential benefits/disadvantages from diversification may diverge because of ownership differences. Although the importance of size in the bank diversification-risk/profitability nexus has been largely documented in the literature, looking into ownership profiles of banks may be more relevant in our study because most foreign banks, which are branches and subsidiaries of foreign banking groups, are considered "small" when we take into account their total assets in the country. Categorizing banks according to size, thus, might underscore the gains from diversification of "large" 
banks. According to the literature, such banks are in a better position to manage operating leverage associated with shifts towards activities generating non-interest income because of economies of scale and their capability to intensively invest in information technology (DeYoung and Roland, 2001).

Bank strategies differ because of differences in customer preferences, information quality and production methods, which could be driven by differences in bank ownership profiles. There is a tendency for foreign-owned institutions or foreign banks to be more oriented towards transactions lending and provide financial services to large corporate clients rather than to lend to smaller firms, more likely catered by domestic banks. Empirical studies show that foreign banks tend to have wholesale orientation and may favorably lend to large corporate affiliates of their customers in their home nation (DeYoung and Nolle, 1996; Grosse and Goldberg, 1991). In addition, foreign banks are more exposed to developed country banking markets, which tend to be more competitive and use more sophisticated information and communication technologies (Claessens et al., 2001). These advantages could favor foreign banks in managing operating and financial leverage when diversifying towards noninterest activities.

To assess the possible divergence in the effect of a shift towards non-interest income by ownership, we test the following extension to Hypothesis 1.

Hypothesis 1a: A shift towards non-interest income will differently impact profitability and risk of banks with different ownership.

We use Model 1 to test Hypothesis 1a on a subsample of foreign banks and domestic banks.

Knowing the sources of non-interest income is important in better understanding the mechanisms by which income diversification may affect a bank's profitability and risk. According to DeYoung and Rice (2004), it is fundamentally misunderstood that commercial banks earn non-interest income mainly from non-traditional banking activities. They demonstrate that the largest source of non-interest income of banks in the U.S. comes from payment services - one of the most traditional of all the banking services. Banks have always traditionally earned non-interest income from deposit account services, lending, cash management and trust account service. Nontraditional banking activities include investment banking, securities brokerage, insurance and trading activities. The growth of traditional banking activities that generate non-interest income is expected to be positively correlated 
with the growth of interest-generating activities like lending ${ }^{27}$ and nontraditional banking activities to be weakly or negatively correlated with interest-generating activities.

We follow Stiroh's (2004a) framework of the decomposition of portfolio growth volatility as shown in Equation 11. Net operating revenue is composed of non-interest income and net interest income. Non-interest income is a function of income from traditional (TRADTL) and nontraditional (NONTRADTL) banking activities.

$$
\begin{gathered}
\sigma_{d \ln O P R E V}^{2}=\alpha^{2} \sigma_{d \ln N O N}^{2}+(1-\alpha)^{2} \sigma_{d \ln N O N}^{2}+2 \alpha(1-\alpha) \operatorname{Cov}(d \ln N O N, d \ln N E T) \\
\text { Where } N O N=f(T R A D T L ; N O N T R A D T L)
\end{gathered}
$$

A shift towards non-interest income generated from traditional banking activities may not imply diversification benefits (or a reduction of diversification benefits) since they are subject to the same fluctuations as interest-generating activities and may lead to increased earnings volatility. This may be the case when banks cross-sell their other financial products to a core customer base. Diversification benefits, however, is higher when a bank shifts toward non-interest income generated from non-traditional banking activities. However, standard portfolio theory also implies that the overall variance of operating revenue rises as the volatilities of the growth rates of income from both traditional and non-traditional banking activities increase.

We disaggregate non-interest income into fee-based, trading and other non-interest income. As shown in Tables $1 \mathrm{~A}$ and $1 \mathrm{~B}$, in the case of banks in the Philippines, we may, however, associate fee-based income and other non-interest income as non-interest income generated from traditional banking activities. Fee-based income are primarily generated from bank commissions collected for services as in opening of letters of credit and sale of demand drafts, and service charges collected for handling loans. Other commissions and fees, which are collected for services in connection with the investment house functions of the bank, however, are low to cause significant variations in the bank's revenue. We highlight this as one of the main differences between banks in emerging economies and developed economies such as the U.S. (DeYoung and Rice, 2004). Moreover, we associate trading income to be non-interest income generated from nontraditional banking activities. We confirm these assumptions by performing pairwise correlations of the growth rates of operating income, its components (interest income and non-interest income) and the non-interest income

\footnotetext{
${ }^{27}$ We do not discount the possibility that the growth of traditional banking activities may be due to the use of new, non-traditional methods, such as advances in information technology.
} 
components (fee-based income, trading income). The growth rate of fee-based income is positively and significantly correlated with the growth rate of net interest income $(0.1568,5 \%$ level of significance) while trading income is weakly and negatively correlated with net interest income growth (-0.0538). Similarly, we also find that the growth of interest income from loans is positively and significantly correlated with fee-based income $(0.1120,10 \%$ level of significance), suggesting that most banks may seize cross-selling opportunities, which may lessen benefits derived from diversification.

We test the following hypothesis,

Hypothesis 2: A shift towards non-interest income from nontraditional banking activities will generate greater diversification benefits than a shift towards non-interest income from traditional banking activities.

This hypothesis will be tested by using a three-level breakdown of non-interest income - fee-based income, trading income and other non-interest income (Model 2a).

\section{Model 2a:}

$\mathrm{Y}_{\mathrm{it}}=\alpha_{\mathrm{it}}+\beta_{1} \mathrm{FOCUS}_{\mathrm{it}}+\beta_{2} \mathrm{FEE}_{\mathrm{it}}+\beta_{3} \mathrm{TRAD}_{\mathrm{it}}+\beta_{4}$ Other $_{\mathrm{it}}+\mathrm{Z}_{\mathrm{it}}+\varepsilon_{\mathrm{it}}$

where $Y_{i t}$ is either a measure of profitability, risk-adjusted profitability or risk; FOCUS2 ${ }_{i t}$ is the measure of diversification based on the breakdown of non-interest income in three components (fee-based, trading and other income); $F E E_{i}, T R A D_{i t}$ and $O$ ther $_{i t}$ are the shares of fee-based income, trading income and other non-interest income, respectively, in total operating income. $\mathbf{Z}_{\mathrm{it}}$ is a vector of control variables.

We use the following control variables - ASSETS, GROWTH, EQUITY, LOANS and GDP in all our models.

ASSETS, is the natural logarithm of bank assets adjusted to the GDP deflator. This variable, following Chiorazzo et al. (2008), Behr et al. (2007), Stiroh and Rumble (2006), and Stiroh (2004a, 2004b) captures the effects of bank size on returns and risk. Larger-sized banks are able to invest in more advanced technologies and generally, have better risk management. They are also able to expand into other business lines. We therefore expect a positive sign for the relationship between size and profits and negative between size and risk.

GROWTH, is the growth rate of total assets. As in Stiroh (2004b) and Chiorazzo et al. (2008), we use this variable as a proxy for bank manager's preference for risk taking. Banks 
with lower risk aversion grow more rapidly and thus, have different operating strategies. Moreover, it may also be interpreted as control for growth-by-acquisition.

$E Q U I T Y$, is the leverage ratio computed as the ratio of total capital to total assets. Banks that hold a lower level of equity in their asset-liability portfolio tend to be riskier. A higher level of capital then translates to the bank manager's risk aversion. This control variable is also used by several bank diversification studies (Chiorazzo et al., 2008, Stiroh, 2004b).

LOANS, is the ratio of total loans to total assets. Consistent with Chiorazzo et al. (2008), Stiroh and Rumble (2006) and DeYoung and Roland (2001), this variable captures the performance of bank's lending strategies relative to its other earning assets.

$G D P$ is the logarithm of the real gross domestic product. This variable controls for macroeconomic fluctuations and overall performance of the economy. We expect a positive sign as banks tend to expect higher profits when the economy is doing well.

We run two-way fixed-effects panel regressions to estimate our models. In performing these estimations, we check for the appropriateness of our estimation method using the Hausman test to check whether a fixed effects model is more appropriate than a random effects model. In addition, we use a Huber/White estimator of variance that is robust to some types of misspecifications along with the fixed effects model.

Since the alternative dependent variables we use, particularly profitability, show the tendency to persist in time ${ }^{28}$, reflecting impediments to competition, informational asymmetry, and change in business strategies, we consider that their previous values could partially determine their current values (Berger et al., 2000). We therefore also estimate our equations using a dynamic model using the methodology proposed by Arellano and Bover (1995) and Blundell and Bond (1998). In this approach, the system of equations is simultaneously estimated in both first-differences and levels. The two step GMM estimator is used to provide a more robust inference from the results. However, we also use the one-step estimator $^{29}$. Since we are considering a small sample, the two step standard errors are computed to conform to Windmeijer's (2005) finite-sample correction. We also take into account the possibility that the explanatory variables might not be strictly exogenous, which is presumably the case of the non-interest income variables. Following Maudos and Solis (2009), to address this endogeneity problem, the lagged levels and lagged differences of the explanatory variables are used as instruments. To determine the consistency of the estimators

\footnotetext{
${ }^{28}$ In the banking literature, few studies consider profits to be persistent ( Roland, 1997; Eichengreen and Gibson, 2001; Goddard et al., 2004)

${ }^{29}$ Results using one-step estimators are not reported but are available from the authors on request.
} 
and verify the validity of the instruments, we use a Sargan test of over identifying restrictions. Meanwhile, we also check for the appropriateness of using the Blundell dynamic panel data estimation technique using the statistic proposed by Arellano and Bond (1991) to test the absence of second-order serial correlation of the first difference residuals.

\section{Empirical Results}

Table $2 \mathrm{~A}$ reports the results obtained for Model 1 . The regressions with profitability and risk-adjusted profitability show positive benefits derived from an increase in income diversity and a shift from interest to non-interest income, which is consistent with Hypothesis 1 . The coefficient of the share of non-interest income is positive and highly significant, which is consistent with the results obtained by Chiorazzo et al. (2008), studying Italian banks. This finding, however, is in contrast with several US banking studies like Stiroh (2004a; 2004b) and Stiroh and Rumble (2006) and a study of emerging economies by Sanya and Wolfe (2011), which associates risk-reduction benefits from increased share of NII but no significant effect in terms of risk-adjusted profits.

\section{[Insert Table 2A]}

As discussed in the previous section, a shift towards non-interest income has two effects: a direct effect from an increased reliance on non-interest income and an indirect effect through changes in diversification. Table $2 \mathrm{~B}$ reports the indirect and net effects of a change in the share of non-interest income at various percentile levels of non-interest income share. Regardless of the level of non-interest income, our results suggest that an increased share of non-interest income offers no significant indirect effects through diversification on both profitability and risk-adjusted profitability. To measure the economic significance of these estimates, we consider the net effect of a change in non-interest income share as shown in Table 2B. Evaluating at the $50^{\text {th }}$ percentile value of $N I I$, the results predict that a one standard deviation increase in non-interest income share will lead to an increase in the ROA and SHROA of 0.02 and 2.27, respectively. Moreover, we highlight the decreasing net effects of NII as the level of non-interest income share increases. This result confirms the diminishing marginal benefits when banks diversify beyond risk efficient levels (Stiroh and Rumble 2006).

[Insert Table 2B]

Chiorazzo et al. (2008) argue that the inconsistency with the results of the U.S. and European banking studies is due to structural and regulatory differences between the European and U.S. markets, which include bank size, longevity of fee-based relationships and 
diffusion of credit scoring methods. In our interpretation, the contrast in the results of most U.S. banking studies and our study comes from two main differences between the income structure of the Philippine banking system and that of the US: first, the correlation between the growth rates of interest income and non-interest income and second, the distribution of the components of non-interest income. Stiroh (2004b) shows the relatively high correlation between interest income and non-interest income in US banks from 1984 to 2001, implying less diversification benefits as the banking industry shifts towards non-interest revenue. In the Philippines, however, the correlation between the growth rates of interest income and noninterest income is weak. The diversification benefits from increased economies of scope coupled with the weak correlation between non-interest income growth and interest income growth fuels the positive impact of a shift towards non-interest income on risk-adjusted profitability. We also observe significant differences in the distribution of non-interest income between banks in the Philippines and the U.S. Stiroh (2004b) highlights that in the U.S. in 2000, an average bank's fees and other income comprise $27 \%$ of net operating income while trading income's share in the net operating income is only $3.5 \%$. We show that in the case of the Philippines (Table 1A), in 1999, trading income (16.5\% of net operating income) dominates fee-based income (13.2\%). Consistent with our sample, U.S. banks exhibit high correlation between the growth rates of net interest income and fee-based income, while a weak correlation exists between trading income growth and net interest income growth. This is reasonable as trading income is more dependent on market fluctuations than traditional banking activities, implying greater diversification benefits should a bank decide to shift its interest income towards this particular component (Stiroh, 2004a).

The impact of an increase in income diversification, more precisely, a shift towards non-interest activities on profitability and risk-adjusted profitability diverges according to bank ownership profile. Table 3A shows the results on a subsample of foreign versus domestic banks. Our findings indicate that increased income diversity does not affect profits and risk-adjusted profits both within domestic and foreign banks. The direct effect of an increase in the share of non-interest income, however, translates to higher profits for foreign banks and a positive and significant impact on risk-adjusted profits in both subsamples. To gauge the economic significance of the estimated impact of a shift towards non-interest income, we report the net effects as presented in Table 3B. These estimates predict that a one standard deviation increase in non-interest income share will lead to an increase in the riskadjusted profits of 1.63 and 4.45, respectively, for domestic banks and foreign banks at higher 
shares of $N I I\left(75^{\text {th }}\right.$ percentile). Hence, only the domestic and foreign banks, which are already heavily involved in non-interest activities can actually benefit from a further shift from traditional interest-generating activities to activities that generate non-interest income. Moreover, we highlight that the effect on risk-adjusted profits goes down in the case of domestic banks, as non-interest income increases. In contrast, as foreign banks tend to focus on non-interest activities, a further shift generates bigger risk-adjusted profits. This may suggest that it pays for foreign banks to specialize in non-interest activities, consistent with the studies of Stein (2002), Berger and Udell (2006), which highlight the disadvantage of foreign-owned institutions in collecting soft information that is crucial in lending to small local firms and lack of knowledge of the local domestic market.

[Insert Tables 3A \& 3B]

We report results of the impact of a shift towards the different components of noninterest income on profits and risk-adjusted profits in Table 4. Consistent with our second hypothesis, our findings suggest the presence of greater benefits from diversification if a bank shifts from traditional interest generating activities toward nontraditional banking activities that generate non-interest income. Indeed, we observe positive and significant direct effects of an increase in the share of trading income to operating income on risk-adjusted profits. Moreover, we find a negative effect of a shift towards fee-based income on risk-adjusted profits, which is consistent with several U.S. banking studies like Stiroh and Rumble (2006) and Stiroh (2004b). These results may be driven by the positive correlation between the growth rates of net interest income and fee-based income, implying that cross-selling is highly likely in Philippine banks and the presence of a blurring demarcation line between income from lending and fee-based income. Furthermore, it is reasonable that a shift towards trading income translates to greater benefits from increased diversification as its growth shows weak correlation with traditional banking activities, responding more to different shocks such as market fluctuations.

\section{[Insert Table 4]}

For our control variables, overall, we find that bank size, ASSET, measured by the natural logarithm of bank assets has a positive impact on ROA and SHROA, but of which the impact decreases as the level of non-interest income increases. When we examine the subsample of domestic banks and foreign banks, however, we observe a positive relationship between profits and an increase in bank size but only for foreign banks. This may suggest that foreign banks are better able to exploit scale economies and have more efficient risk 
management techniques. The coefficients associated with LOANS are positive and significant in terms of $R O A$, but only for our fixed effects panel regressions. We do not find, however, any significant relation between an increase in lending activity and risk-adjusted profits. Our results are in line with DeYoung and Rice (2004) but slightly differ from those of Chiorazzo et al. (2008) who find a positive impact of increased loans on risk-adjusted returns. The ratio of equity to total assets has an ambiguous effect on profits and risk-adjusted profits. We observe a negative relationship between ROA and EQUITY, suggesting that an increase in bank capitalization translates to lower profits. Our fixed effects regression results, however, suggests that an increase in bank capitalization increases risk-adjusted profits. GROWTH, meanwhile has contradicting effects on $R O A$, notably in domestic and foreign banks. We find that as banks grow rapidly, profits also soar in the case of domestic banks, while profits decline in the case of foreign banks. We do not find, however, any significant impact of a change in asset growth on risk-adjusted profits. We also control for the level of growth of the economy, GDP, and overall, our results show that expected bank profits and risk-adjusted profits benefit from stronger economic growth.

\section{Further Investigation}

\subsection{SME Lending and Income Diversification}

The history of Philippine banking reveals a developmental role assigned to the banking system. Several mandated credit programs are imposed with the aim of allocating credit to sectors that are critical from a social standpoint. Lending targets set for priority sectors are imposed in several emerging economies like India, Afghanistan, the Philippines, Pakistan and Sri Lanka (CGAP Financial Access 2010). From a theoretical point of view, mandated credit programs are inefficient ways to allocate scarce financial resources, potentially distorting bank strategies (Medalla and Ravalo, 1997).

One of the mandated credit programs in the Philippines is the Magna Carta for Small and Medium Enterprises (SMEs). As stipulated in the RA 6977 $7^{30}$, all lending institutions, such as banks are mandated to set aside at least six percent (6\%) and at least two percent (2\%) of their total loan portfolio to small and medium enterprises, respectively. There are, however, alternative ways to comply with this specific regulation. Banks may subscribe to the preferred

\footnotetext{
${ }^{30}$ Republic Act No. 6977 (later amended by Republic Act No. 8929)- An act to promote, develop and assist small and medium scale enterprises through the creation if a Small and Medium Enterprise Development (SMED) Coucil, and the rationalization of government assistance, programs and agencies concerned with the development of Small and Medium Enterprises, and for other purposes. It was later amended by Republic Act No. 9501 in 2008 to increase the percentage set aside for small enterprises from six percent (6\%) to eight percent (8\%).
} 
shares of the Small Business Guarantee and Finance Corporation (SBGFC) or subscribe or purchase liability instruments as may be offered by $\mathrm{SBGFC}^{31}$.

As highlighted in the literature (Berger and Udell, 2001), small business lending tends to rely more on relationship lending where banks have to gather soft information. Although recent literature suggests several lending technologies such as credit scoring and factoring may be used by banks to cater to informationally opaque small firms, large banks in emerging economies may still find it difficult to use these technologies because they require efficient and good information infrastructure. The alternative ways of complying may thus be more desirable from the point of view of larger and foreign banks as they are also less likely to be involved in relationship lending. Moreover, foreign banks, which do not have the specific knowledge of local domestic markets, could be disadvantaged in collecting soft information, which is vital in relationship lending.

We report in Table 5 the aggregate data on the compliance to the Magna Carta for Small and Medium Enterprises of the universal and commercial banks (UKBs) over the period of study. Although the UKBs collectively allocate more funds than the minimum amount to be allocated for SMEs (in 2005, 19.77\% versus the required 8\%), an average of $2.07 \%$ alternative/indirect compliance (to total net loan portfolio) indicates the presence of banks that do not comply by lending to the set minimum. The distribution of the total credit to SMEs, however, is disproportionate. Of the $19.77 \%$ compliance to the mandated credit to SMEs, $9.24 \%$ (versus $6 \%$ required) are allocated to small enterprises, while $10.53 \%$ (versus $2 \%$ required) are allotted to medium enterprises. It is also worthy to note that funds set aside to $\mathrm{SMEs}^{32}$, which is also another way to comply to the Magna Carta for Small and Medium Enterprises has been consistently increasing over the period of study.

\section{[Insert Table 5]}

Because of the organizational diseconomies of providing relationship lending services along with providing transactions lending and other wholesale capital market services to large corporate customers, it may be too costly to provide financial services to small firms while maintaining provision of different banking services to large clients (Berger et al., 2001). A shift towards non-interest income may therefore more likely benefit banks that are less inclined to directly comply with the Magna Carta for SMEs by lending, indicating their expertise on the provision of other financial services besides lending.

\footnotetext{
${ }^{31}$ This organization is now known as the Small Business Corporation

32 Consists of either Cash on Hand and Due from BSP which are free, unencumbered, not hypothecated, not utilized or earmarked for other purposes. The Due from BSP is a special account deposited with the BSP and does not form part of the bank's legal reserves. Under the new mandatory credit allocation (RA 9501) beginning 2008, Funds Set Aside is no longer considered as a mode of compliance.
} 
Since we do not have detailed information which provides disaggregated data of the compliance ratios $^{33}$ of individual banks isolating direct lending from alternative compliance, we group banks according to their compliance ratios that may reveal their behavior towards SME lending. We group banks according to their level of compliance: 1) banks that comply to the mandated credit program by holding more SME loans than required in their loan portfolio and 2) banks that are lending to SMEs because they are required by law, and thus have compliance ratios to the Magna Carta for SMEs that are close to the minimum. These banks are also more likely to alternatively comply by purchasing liability instruments or set aside funds for small enterprises ${ }^{34}$. Data on compliance ratios for individual banks are only available from 2005. We primarily look into bank compliance ratios to the Magna Carta for SMEs in 2005. Moreover, we check that the categorizations are robust by looking at average bank compliance ratios from 2005 to 2007 . We identify 25 banks which are less likely to comply through direct lending and 12 banks, with compliance ratios greater than or equal to $1.2 \% *$ MinimumLegalLimit (where MinimumLegalLimit $=6 \%)^{35}$. We test Hypothesis 1 on these two subsamples.

The results of the estimations are shown in Table 6A while the estimated impact of a shift towards non-interest income is reported in Table 6B. In terms of profitability, the findings indicate that a shift towards non-interest income increases profitability (through the direct effect and net effect) but only for banks that alternatively comply to the mandated SME lending program by acquiring designated securities or those that have low lending exposure to smaller firms. Conversely, banks that lend to SMEs more than what is required by law do not derive greater profits from shifting traditional interest-generating activities to non-interest generating ones. These results suggest that universal and commercial banks that lend more to SMEs benefit less from diversification. More importantly, they highlight the presence of additional opportunity costs from lending to SMEs, in the form of lost profits, especially for the larger banks and most foreign banks that do not have expertise in lending to small businesses. Even with the presence of mandated credit programs, these banks may not have incentives to reallocate their funds towards priority sectors, such as the SMEs.

[Insert Tables 6A \& 6B]

\subsection{Listed Banks}

\footnotetext{
33 Our data of the compliance ratios of the Magna Carta for SMEs of individual banks do not distinguish direct compliance through lending and alternative compliance through several means.

${ }^{34}$ We focus our study on the micro and small enterprises, where bank financing may be more constrained compared with medium enterprises. In addition, most of the MSMEs in the Philippines belong to the micro and small enterprises group (90\%). It is also more probable that banks alternatively comply in the micro and small enterprises group than in the medium enterprises group.

${ }^{35}$ We also use several other coefficients such as 1.1 and 1.3 and obtain similar results.
} 
We also study the effects of income diversification on the risk, profitability and riskadjusted profitability of listed and universal listed banks in the Philippines. Unlike commercial banks, universal banks are allowed to perform the activities of investment houses $\left(\right.$ RA $8791^{36}$, PD $129^{37}$ ) and generally, are bigger in terms of size. Hence, the impact of income diversification may diverge between the two types of banks. Because of a scope and size advantage, we argue that universal banks are in a better position to diversify away from traditional interest-generating activities towards activities that generate non-interest income, particularly the non-traditional ones. We thus study the listed and universal listed banks ${ }^{38}$ and test hypotheses 1 and 2. The results are reported in Tables 7 and 8 . While we find in both subsamples a positive and significant direct effect of a shift towards non-interest income on profitability and risk-adjusted profitability, the value of the coefficient is higher in the case of universal listed banks. Moreover, in terms of risk, our results suggest that universal listed banks derive greater risk-reduction benefits from an increase in the share of non-interest income derives using market-based indicators. This result is driven primarily by a shift towards trading income, effectively increasing profits, reducing risk and hence, increasing risk-adjusted profits.

\section{[Insert Tables $7 \&$ 8]}

\subsection{Components of Trading and Fee-based Income $\mathbf{~}^{39}$}

We also examine the effects of a shift towards more specific/detailed fee-based and trading activities. We extend Hypothesis 2, investigating further the impact of a shift towards a traditional or a non-traditional banking activity, which earns non-interest income on profits and risk-adjusted profits. While this may have been studied using U.S. data as in Stiroh and Rumble (2006), this is the first study on an emerging economy that provides more details on the fee-based and trading income components of banks.

We construct two new measures that take into account the separate components of feebased and trading income. We run a new set of regressions on the basis of the following models:

$\mathrm{Y}_{\mathrm{it}}=\alpha_{\mathrm{it}}+\beta_{1} \mathrm{FOCUS3}_{\mathrm{it}}+\beta_{21} \mathrm{BC}_{\mathrm{it}}+\beta_{22} \mathrm{SC}_{\mathrm{it}}+\beta_{23} \mathrm{OC}_{\mathrm{it}}+\beta_{3} \mathrm{TRAD}_{\mathrm{it}}+\beta_{4} \mathrm{Other}_{\mathrm{it}}+\mathrm{Z}_{\mathrm{it}}+\varepsilon_{\mathrm{it}}$

\footnotetext{
${ }^{36}$ Republic Act No. 8791. An Act Providing For the Regulation of the Organization and Operations of Banks, Quasi-Banks, Trust Entities and for Other Purposes. Artcile 1, Section 23. Powers of a Universal Bank. - A universal bank shall have the authority to exercise, in addition to the powers authorized for a commercial bank, the powers of an investment hourse as provided in existing laws and the power to invest in non-allied enterprises.

${ }^{37}$ Presidential Decree No. 129. The Investment Houses Law. Section 2. Definitions: A) Investment House is any enterprise which primarily engages, whether regularly or on an isolated basis, in the underwriting of securities of another person or enterprise, including securities of the Government or its instrumentalities.

${ }^{38}$ Since there are not enough observations to investigate commercial listed banks, we compare all listed and universal banks.

${ }^{39}$ Table of results not reported but available upon request from the authors
} 


$$
\mathrm{Y}_{\mathrm{it}}=\alpha_{\mathrm{it}}+\beta_{1} \mathrm{FOCUS}_{i t}+\beta_{2} \mathrm{FEE}_{\mathrm{it}}+\beta_{31} \mathrm{GS}_{\mathrm{it}}+\beta_{32} \mathrm{PD}_{\mathrm{it}}+\beta_{33} \mathrm{FF}_{\mathrm{it}}+\beta_{34} \mathrm{PI}_{\mathrm{it}}+\beta_{35} \mathrm{FP}_{\mathrm{it}}+\beta_{4} \mathrm{Other}_{\mathrm{it}}+\mathrm{Z}_{\mathrm{it}}+\varepsilon_{\mathrm{it}}
$$

FOCUS3 $_{i t}$ and FOCUS4 ${ }_{i t}$ are measures of diversification within respectively detailed fee-based and trading incomes; $B C_{i t}, S C_{i t}$ and $O C_{i t}$ are the three components of fee-based activities and represent the shares of, respectively, bank commissions, service charges and other commissions in total operating income. $G S_{i t}, P D_{i t}, F F_{i t}, P I_{i t}$ and $F P_{i t}$ are the five components of trading activities and represent the shares of, respectively, government securities trading gains (losses), private debt trading gains (losses), financial futures gains (losses), and profit from investment and foreign exchange profits in total operating income.

In contrast with Chiorazzo et al. (2008), we find that gains from diversification are associated with the source of non-interest income. Our findings are not in line with studies on U.S. banks (i.e. Stiroh, 2004b) which report higher risk for banks more reliant on trading activities. However, for European banks, Lepetit et al. (2008) do not find evidence of a positive relationship between trading activities and risk.

The econometric investigation conducted on the detailed breakdown of fee-based and trading activities provides a clearer insight of how different product mixes within non-interest activities affect profitability and risk. Two main results are highlighted. First, in the case of fee-based activities, we find that an increased share of "other commissions and fees" to total operating income is associated with increased profitability but not risk-adjusted profitability. The second result relates to trading income. We find that a shift towards trading government securities and financial futures/options/forward/swaps, both non-traditional banking activities, lead to enhanced profitability and risk-adjusted profitability.

Further differences in the diversification effect of Philippine banks into non-interest activities are analyzed by examining the specific case of universal banks, which unlike commercial banks, are allowed to perform the activities of investment houses (RA $8791^{40}$, PD $129^{41}$ ). Following existing studies (Bhargava and Fraser (1998), Akhigbe and Whyte (2004), Cornett et al. (2002)) which examine the effects of various regulations that pertain to bank expansion into investment banking activities, our aim here is to assess the risk implications of diversifying into such specific non-interest activities. We investigate the effects of the disaggregated shares of fee-based and trading income on the risk of universal banks and focus more particularly on the effect of increased shares in "other commissions/fees" (a component

\footnotetext{
${ }^{40}$ Republic Act No. 8791. An Act Providing For the Regulation of the Organization and Operations of Banks, Quasi-Banks, Trust Entities and for Other Purposes. Artcile 1, Section 23. Powers of a Universal Bank. - A universal bank shall have the authority to exercise, in addition to the powers authorized for a commercial bank, the powers of an investment hourse as provided in existing laws and the power to invest in non-allied enterprises.

${ }^{41}$ Presidential Decree No. 129. The Investment Houses Law. Section 2. Definitions: A) Investment House is any enterprise which primarily engages, whether regularly or on an isolated basis, in the underwriting of securities of another person or enterprise, including securities of the Government or its instrumentalities.
} 
of fee-based income), which are commission and fees collected for investment house activities such as underwriting, securities dealership and equity investments, the nontraditional income component of fee-based activities. Our results show that in the case of universal banks, a shift towards investment house activities, although leading to higher profits, has an adverse effect on risk. This is consistent with some studies on developed countries that find shifts towards fee-based activities to be risky. Fee-based income earned from the investment house functions are, however, small compared to other fee-based components. Looking further on the disaggregation of trading income, we find that higher involvement in trading government securities leads to risk reduction, enhancing both profitability and risk-adjusted profitability.

\section{Robustness Checks ${ }^{42}$}

We also perform several robustness checks. First, we define alternative measures of diversification, particularly FOCUS1. As the index predicts the same degree of focus for banks that are more reliant on interest income, and for those that are more oriented towards non-interest income, it does not allow us to differentiate on which activities the bank is focused on. We then define another indicator, FOCUSDIV, which is the interaction term of FOCUS1 with a dummy variable, DIV, which is equal to 1 if the share of non-interest income is higher than $50 \%$ and zero, otherwise. The coefficient of FOCUSDIV indicates whether it pays to be more focused on non-interest activities compared to interest-generating ones. We also examine different thresholds of $D I V-30 \%, 40 \%$ and $60 \%$ and find that at a threshold of non-interest income less than $40 \%$, focus on non-interest income does not translate into increased bank profitability. Moreover, with thresholds greater than $40 \%$, we find that focus increases bank profitability. Our results are very robust to the $60 \%$ and $70 \%$ thresholds, which confirm that focusing in activities that generate non-interest income increases the profitability of Philippine banks.

Second, we use a more limited definition of trading income, which includes only the gains/losses from trading activities (government securities, private/equity securities, and financial futures options/forwards/swaps). When this definition is used, we find "other noninterest income" to be positively related to profitability and risk. This can be explained by the inclusion of other non-traditional, non-interest income generating activities like foreign exchange profit, gold trading gain/loss and the profit on sale or redemption of investments in

\footnotetext{
${ }^{42}$ For the sake of brevity, we do not report all the results discussed under the section of robustness check. However, the results are available from the authors on request.
} 
our definition of "other non-interest income", driving up diversification benefits, notably riskadjusted profitability. The results however regarding trading income remain unchanged.

We also examine if there are significant behavioral differences between listed and non-listed banks. We do not find, however, significant differences over these two subsamples.

\section{Summary and concluding remarks}

Research on bank revenue diversification in developed countries, namely the U.S., has documented that a higher reliance on non-interest activities lowers risk-adjusted profits (Stiroh, 2004a, 2004b, 2006 and Stiroh and Rumble, 2006). In this paper, we find diversification to be beneficial for Philippine banks, consistent with Sanya and Wolfe (2011) who study the income diversification-performance relationship of listed banks in 11 emerging economies. Philippine banks have a different non-interest income structure. For an average Philippine bank, the share of trading activities in non-interest income is relatively higher compared with an average U.S. bank. Whereas most of the fee-based income is obtained from traditional bank intermediation activities, trading income is nontraditional as its growth is less correlated with net interest income growth. From a standard portfolio approach, this may indicate that there may be higher diversification benefits from shifts towards trading income activities rather than shifts towards fee-based income activities. Our empirical results support this hypothesis, suggesting that that shifts toward trading income, particularly from trading government securities, lead to higher bank profits and risk-adjusted profits.

We also examine how bank ownership may affect the income diversificationperformance relationship. Our findings indicate that foreign banks have the upper hand in diversifying income compared with domestic banks. As foreign banks tend to specialize in non-interest income activities, a marginal increase in non-interest income tends to increase further their risk-adjusted profits. In emerging countries, foreign banks generally suffer from insufficient knowledge of the local market and disadvantage in terms of collecting soft information, which may be vital in lending not only to small businesses but also to larger firms. Thus it pays for them to specialize in non-interest income generating activities rather than traditional intermediation activities.

We take our investigation deeper by tackling a specific regulatory aspect that is akin to emerging economies - the presence of mandated credit programs to SMEs. Particularly, we investigate the extent by which increased income diversification affects profitability and risk differently across banks with high and low exposures to SME financing. We find revenue diversification, more precisely, a shift towards non-interest income to benefit banks that lend 
less to SMEs. This result suggests that for these banks, the presence of an additional opportunity cost in the form of lost profits further dissuades them to directly lend to SMEs. The existence of alternative ways to comply with the regulation, i.e. by acquiring specific government securities, may have hastened bank inefficiency generally attributed to mandated credit programs but at the expense of the social purpose of such development programs that aim to increase sustainable access to external finance to SMEs. Nevertheless, banks that allocate a higher percentage of their loan portfolio to SMEs are assumed to have appropriate lending technologies that address opaque small business borrowers and relatively less expertise in diversifying into non-interest activities, which may arise because of high switching costs. On the whole, our findings highlight that the development of nontraditional intermediation activities in banking have different implications in terms of profitability and risk in the case of an emerging economy. Specifically, bank ownership (foreign/domestic) and the engagement in SME funding as well as the presence of specific regulations to promote small scale lending matter.

\section{References}

Akhigbe, A., Whyte, A.M., 2004. The Gramm-Leach-Bliley Act of 1999: Risk Implications for the financial services industry. The Journal of Financial Research. 27, 435-446.

Arellano, M., Bond, R.M., 1991. Some tests of specification for panel data: Monte Carlo evidence and application to employment equations. Review of Economic Studies. 58, 277-297.

Arellano, M., Bover, O., 1995. Another look at the instrumental-variable estimation of errorcomponents models. Journal of Econometrics. 68, 29-51

Baum, C., 2006. An Introduction to Modern Econometrics using Stata,TX: Stata Press Publication.

Behr, A., Kamp, A., Memmel, C., Pfingsten, A., 2007. Diversification and the banks' riskreturn-characteristics- evidence from loan portfolio of German banks. Deutsche Bundesbank, Discussion Paper, Series 2: Banking and Financial Studies.

Berger, A.N., Bonime, S,.D., Covitz, D.M., Hancock, D., 2000. Why are bank profits so persistent? The roles of product market competition, informational opacity, and regional/macroeconomic shocks. Journal of Banking and Finance. 24, 1203-1235

Berger, A. N., Hasan, I., Zhou, M., 2010. The effects of focus versus diversification on bank performance: Evidence from Chinese banks. Journal of Banking and Finance. 34, $1417-$ 1435. 
Berger, A.N., Klapper, L., Udell, G., 2001. The ability of banks to lend to informationally opaque small businesses. Journal of Banking and Finance. 25, 2127-2167.

Berger, A., Udell, G.F., 2006. A More Complete Conceptual Framework for Financing of Small and Medium Enterprises. Journal of Banking and Finance.

Bhargava, R., Fraser, D., 1998. On the wealth and risk effects of commercial bank expansion into securities underwriting: An analysis of Section 20 subsidiaries. Journal of Banking and Finance. 22, 447-465.

Blundell, R.W., Bond, S.R., 1998. Initial conditions and moment restrictions in dynamic panel data models. Journal of Econometrics. 87, 115-143

Boyd, J. H., Graham, S.L., Hewitt, R.S., 1993. Bank holding company mergers with nonbank financial firms: effects on the risk of failure. Journal of Banking and Finance. 17, 43-63.

Chiorazzo, V., Milani, C., Salvini, F., 2008. Income Diversification and Bank Performance: Evidence from Italian Banks. Journal of Financial Services Research. 33, 181-203.

Claessens, S., Demirgüç-Kunt, A., Huizinga, H., 2001. How Does Foreign Entry Affect Domestic Banking Markets?. Journal of Banking and Finance. 25, 891-911.

Clarke, G., R. Cull, Martinez-Peria M. S., 2006. Foreign bank participation and access to credit across firms in developing countries. Journal of Comparative Economics. 34, 774-795.

Cornett, M., Ors, E., Tehranian, H., 2002. Bank performance around the introduction of a Section 20 subsidiary. Journal of Finance. 57, 501-523.

De Nicolo, G., Loukoianova, E., 2007. Bank Ownership, Market Structure and Risk, IMF Working Paper, 07/215.

Demsetz, R.S., Strahan, P.E., 1997. Diversification, size and risk at bank holding companies. Journal of Money, Credit and Banking. 29, 300-313.

Detragiache, E., Tressel T., Gupta P., 2008. Foreign Banks in Poor Countries: Theory and Evidence. Journal of Finance. 5, 2123-2160

DeYoung, Robert, and Nolle D. E., 1996. Foreign-owned banks in the US: buying market share or earning it. Journal of Money, Credit, and Banking. 28, 622-636.

DeYoung, R. and Rice, T., 2004. How do banks make money? The fallacies of fee income. Economics Perspectives. 34-51.

DeYoung, R., Roland, K.P., 2001. Product mix and earnings volatility at commercial banks: evidence from a degree of leverage model. Journal of Financial Intermediation. 10, 5484 
Eichengreen, B., Gibson, H.D., 2001. Greek banking at the dawn of the new millennium. CERP Discussion Paper 2791, London.

Financial Access 2010 Report. Consultative Group to Assist the Poor/The World Bank Group. Gochoco-Bautista, M., 1999. The Past Performance of the Philippine Banking Sector and Challenges in the Postcrisis Period, Rising to the Challenge in Asia: A Study of Financial Markets, Philippines, Asian Development Bank, 10, 29-77.

Goddard, J., Molyneux, P., Wilson, J.O.S, 2004. The profitability of European banks: a crosssectional and dynamic panel analysis. Manchester School. 72, 363-381.

Gormley, T. A., 2010. The impact of foreign bank entry in emerging markets: Evidence from India. Journal of Financial Intermediation. 19, 26-51

Grosse, R. and Goldberg, L., 1991. Foreign Activity in the United States: An Analysis by Country of Origin. Journal of Banking and Finance. 15, 1092-1112

Hawkins, J and Mihaljek D., 2001. The banking industry in the emerging market economies: competition, consolidation and systemic stability: an overview. BIS Papers. 4.

Klein, PG and Saidenberg, M.R., 1997. Diversification, organization and efficiency: evidence from bank holding companies. Working Paper 97-27, Wharton School Center for Financial Institutions, University of Pennsylvania.

Lensink, R., Hermes, N., 2003. The Short-term Effects of Foreign Bank Entry on Domestic Bank Behaviour: Does Economic Development Matter?. Journal of Banking and Finance. 27.

Lepetit, L., Nys, E., Rous, P., Tarazi, A., 2008a. Bank income structure and risk: An Empirical Analysis of European Banks. Journal of Banking and Finance. 32, 14521467.

Lepetit, L., Nys, E., Rous, P., Tarazi, A., 2008b. The expansion of services in European banking: implications for loan pricing and interest margins. Journal of Banking and Finance. 32, 2325-2335.

Maudos, J., Solis, L., 2009. The determinants of net interest income in the Mexican banking system: an integrated model. Journal of Banking and Finance. 33, 1920-1931.

Medalla, F. and Ravalo, J.N., 1997. The Impact of Mandated Credit Programs on Financial Institutions.

Mercieca, S., Schaeck K., Wolfe S., 2007. Small European banks: Benefits from Diversification?. Journal of Banking and Finance. 31, 1975-1998

Roland, K., 1997. Profit persistence in large US bank holding companies: An empirical investigation, OCC Working Paper. 
Sanya, S., Wolfe, S., 2011. Can banks in Emerging countries benefit from revenue diversification?. Journal of Financial Services Research. 40, 79-101.

Shleifer A., 1998. State versus private ownership. Journal of Economic Perspectives. 12, 133150.

Shleifer A., Vishny R.W., 1998. The grabbing hand: government pathologies and their cures, Harvard University Press, MA

Stein, J., 2002. Information Production and Capital Allocation: Decentralized versus Hierarchical Firms. Journal of Finance. 57, 1891-1921.

Stiroh, K.J., 2004a. Do community banks benefit from diversification?. Journal of Financial Service Research. 25, 135-160.

Stiroh, K.J., 2004b. Diversification in banking: is non-interest income the answer? Journal of Money, Credit and Banking. 36, 853-882.

Stiroh, K.J., 2006. New Evidence on the Determinants of Bank Risk. Journal of Financial Service Research. 30, 237-263.

Stiroh, K.J., Rumble, A., 2006. The dark side of diversification: the case of U.S. financial holding companies. Journal of Banking and Finance. 30, 2131-2161.

Windmeijer, F., 2005. A finite sample correction for the variance of linear efficient two-step GMM estimators. Journal of Econometrics. 126, 25-51. 


\section{APPENDIX: Definitions}

\section{NON-INTEREST INCOME ACCOUNTS}

Fee-based Income: sum of bank commissions, service charges/fees and other commissions/fees

Bank Commissions: commissions collected for services rendered as in: (a) opening of letters of credit, (b) handling of collection items, domestic/export/import bills and telegraphic transfers, and (c) sale of demand drafts, traveller's checks and government securities

Service charges: charges/fees, including commitment fees, collected for services rendered as in: (a) handling of loans and transactions and returned checks, (b) sale of manager's checks.

Fees/commissions (others): fees and commissions earned and collected for services rendered in connected with the investment house functions of the bank such as underwriting, securities dealership and equity investments.

Trading income: sum of trading gain from government securities, private securities/commercial papers/equity securities, financial futures/options/forwards/swaps; foreign exchange profit/loss, gold trading gain/loss; profit on sale or redemption of investments.

Trading gain (government securities): gain or loss on government securities traded in money market operations.

Trading gain (private securities/commercial papers/equity securities): gain or loss in private securities/commercial papers/equity securities traded by the bank.

Trading gain (financial futures/options/forwards/swaps): trading profits and loss (both realized and "mark-to-market") arising from financial futures/options/forward/swap trading transactions.

Foreign exchange profit: realized profit or actual loss incurred on foreign exchange transactions, including profit or loss arising from the adjustment of the peso equivalent of foreign monetary accounts consisting of foreign currencies on hand, due from foreign banks and short-term receivables/payables.

Profit on sale or redemption of investments: profits earned or loss incurred on the sale or redemption of investments.

Other non-interest income: sum of income from trust department and other income

Income (trust department): commissions and other income earned and collected or loss suffered by the bank's trust department in the handling/administration of trust accounts.

Other income: rental income and miscellaneous income

(Source: Manual of Accounts for Universal and Commercial Banks, Central Bank of the Philippines) 
TABLES

Table 1A: Descriptive statistics for Philippine universal and commercial banks over the 1999-2005 period

\begin{tabular}{|c|c|c|c|c|c|c|c|c|c|c|c|c|c|c|c|}
\hline & \multicolumn{3}{|c|}{ Whole sample } & \multicolumn{3}{|c|}{ Large Banks } & \multicolumn{3}{|c|}{ Large Banks excluding government banks } & \multicolumn{3}{|c|}{ Medium-sized Banks } & \multicolumn{3}{|c|}{ Small Banks } \\
\hline & 1999 & 2005 & 1999-2005 & 1999 & 2005 & 1999-2005 & 1999 & 2005 & $1999-2005$ & 1999 & 2005 & $1999-2005$ & 1999 & 2005 & $1999-2005$ \\
\hline Assets & 71.7 & 102 & 87.9 & 208 & 272 & 253 & 211 & 277 & 266 & 53.4 & 101 & 69.6 & 12.1 & 18.3 & 13.9 \\
\hline Loans & 50.4 & 48.98 & 49.02 & 52.53 & 46.62 & 49.59 & 52.44 & 46.22 & 49.81 & 55.22 & 39.7 & 46.22 & 45.54 & 56.79 & 50.96 \\
\hline Equity & 13.1 & 11.11 & 12.94 & 11.68 & 9.34 & 11.09 & 12.3 & 9.31 & 11.49 & 12.72 & 10.24 & 11.81 & 14.15 & 12.61 & 14.86 \\
\hline Deposits & 57.88 & 56.9 & 58.88 & 68.98 & 64.79 & 64.7 & 68.47 & 70.19 & 70.03 & 69.04 & 67.72 & 70.5 & 43.32 & 45.23 & 46.39 \\
\hline NII & 34.16 & 32.49 & 35.92 & 35.65 & 31.45 & 38.16 & 35.54 & 35.35 & 43.53 & 34.64 & 36.15 & 39 & 32.99 & 30.41 & 32.22 \\
\hline FEE & 13.16 & 13.56 & 13.37 & 12.75 & 13.9 & 14.14 & 14.39 & 17.85 & 17.48 & 14.94 & 11.87 & 13.6 & 12.01 & 14.59 & 12.78 \\
\hline $\mathrm{BC}$ & 4.07 & 3.7 & 4.01 & 3.69 & 3 & 3.93 & 4.19 & 4.08 & 5.06 & 4.29 & 2.37 & 2.68 & 4.12 & 5.01 & 5.14 \\
\hline $\mathrm{SC}$ & 7.68 & 7.93 & 8.07 & 7.81 & 9.74 & 8.96 & 8.77 & 12.26 & 10.88 & 9.9 & 9.41 & 10.64 & 5.91 & 5.97 & 5.53 \\
\hline $\mathrm{OC}$ & 1.4 & 1.93 & 1.29 & 1.25 & 1.17 & 1.25 & 1.44 & 1.51 & 1.53 & 0.76 & 0.08 & 0.28 & 1.98 & 3.63 & 2.12 \\
\hline TRAD & 16.48 & 14.29 & 16.82 & 15.77 & 11.51 & 15.45 & 13.18 & 10.95 & 16.24 & 14.65 & 18.09 & 19.47 & 18.27 & 12.97 & 15.41 \\
\hline GS & 5.45 & 6.79 & 6.8 & 3.21 & 3.91 & 6.93 & 3.47 & 5.89 & 8.76 & 4.87 & 13.1 & 9.78 & 6.89 & 4.31 & 4.58 \\
\hline PD & 2.43 & 0.6 & 2.14 & 2.87 & 1.85 & 1.82 & 0.94 & 1.55 & 1.67 & 4.7 & 0.06 & 2.16 & 0.66 & 0.39 & 2.27 \\
\hline $\mathrm{FF}$ & 0.04 & 0.26 & 0.39 & 0 & 0.52 & 0.6 & 0 & 0.08 & 0.57 & 0.03 & 0.47 & 0.59 & 0.07 & 0.03 & 0.16 \\
\hline PI & 0.86 & 1.44 & 1.43 & 2.84 & 3.27 & 2.64 & 0.35 & 2.27 & 1.04 & 0.79 & 2.01 & 2.43 & 0 & 0.11 & 0.2 \\
\hline FP & 8.38 & 5.78 & 6.65 & 6.67 & 5.04 & 6.39 & 7.52 & 4.7 & 7.16 & 6.2 & 3.27 & 5.02 & 10.64 & 7.6 & 8.03 \\
\hline Other & 4.52 & 4.64 & 5.85 & 7.13 & 6.03 & 8.81 & 7.96 & 6.55 & 10.16 & 5.04 & 6.19 & 6.05 & 2.71 & 2.84 & 4.09 \\
\hline ROA & 0.62 & 1.54 & 0.94 & 0.33 & 1.04 & 0.76 & 0.33 & 0.97 & 0.68 & 0.75 & 1.02 & 0.92 & 0.67 & 2.14 & 1.04 \\
\hline
\end{tabular}

Variable definitions (All variables are expressed in percentage except for total assets, which is expressed in billion pesos) Loans: ratio of net loans to total assets; Equity: ratio of equity to total assets; Deposits: ratio of total deposits to total assets; NII: ratio of non-interest income to total net operating income; FEE: ratio of fee-based income to total net operating income; BC: ratio of bank commissions and fees to total net operating income; SC: ratio of service charges to total net operating income; OC: ratio of other commissions and fees to total net operating income; TRAD: ratio of trading income to total net operating income; GS: ratio of income from trading government securities to total net operating income; PD: ratio of income from trading private debt/equity to total net operating income; FF: ratio of income from trading financial futures and other derivatives to total net operating income; PI: ratio of profit from sale of investments to total net operating income; FP: ratio of foreign exchange profit to total net operating income; Other: ratio of other non-interest income to total net operating income; ROA: return on average asset; ROE: return on average equity. 
Table 1A (continued). Descriptive statistics for Philippine universal and commercial banks over the 1999-2005 period

\begin{tabular}{|c|c|c|c|c|c|c|c|c|c|c|c|c|c|c|c|}
\hline & \multicolumn{3}{|c|}{ Domestic Banks } & \multicolumn{3}{|c|}{ Domestic Banks (excluding government banks) } & \multicolumn{3}{|c|}{ Foreign Banks } & \multicolumn{3}{|c|}{ Universal Banks } & \multicolumn{3}{|c|}{ Commercial Banks } \\
\hline & 1999 & 2005 & 1999-2005 & 1999 & 2005 & 1999-2005 & 1999 & 2005 & 1999-2005 & 1999 & 2005 & All & 1999 & 2005 & 1999-2005 \\
\hline Assets & 104 & 141 & 119 & 98 & 127 & 110 & 29.8 & 41.1 & 32.8 & 127 & 190 & 169 & 10.7 & 37.2 & 26.9 \\
\hline Loans & 53.81 & 43.69 & 47.95 & 53.87 & 43.22 & 47.86 & 45.93 & 57.36 & 50.93 & 55.61 & 44.42 & 48.67 & 48.63 & 41.52 & 46.73 \\
\hline Equity & 17.16 & 12.42 & 15.63 & 17.74 & 12.77 & 16.17 & 7.78 & 9.03 & 8.13 & 14.33 & 11.28 & 13.41 & 27.95 & 14.91 & 20.07 \\
\hline Deposits & 68.6 & 66.24 & 65.46 & 68.38 & 68 & 67.11 & 43.87 & 42.12 & 47.08 & 69.96 & 71.25 & 71.39 & 63.63 & 63.36 & 61.07 \\
\hline NII & 33.08 & 33.05 & 36.02 & 32.87 & 34.38 & 37.41 & 35.57 & 31.62 & 35.73 & 31.95 & 36.86 & 39.38 & 35.65 & 30.84 & 34.62 \\
\hline Fee-based & 11.41 & 11.59 & 11.59 & 11.94 & 12.48 & 12.34 & 15.46 & 16.67 & 16.57 & 10.8 & 12.89 & 12.66 & 15.37 & 11.9 & 11.89 \\
\hline $\mathrm{BC}$ & 2.4 & 2.2 & 2.52 & 2.51 & 2.43 & 2.73 & 6.26 & 6.1 & 6.69 & 2.95 & 3.09 & 3.4 & 1.19 & 1.48 & 1.77 \\
\hline $\mathrm{SC}$ & 7.86 & 7.8 & 8.17 & 8.22 & 8.31 & 8.67 & 7.45 & 8.14 & 7.89 & 6.86 & 9.05 & 8.49 & 12.31 & 7.26 & 8.93 \\
\hline OC & 1.15 & 1.59 & 0.89 & 1.21 & 1.74 & 0.94 & 1.73 & 2.46 & 1.99 & 0.99 & 0.75 & 0.77 & 1.87 & 3.16 & 1.19 \\
\hline Trading & 16.05 & 15.72 & 17.83 & 15.1 & 16.06 & 18.29 & 17.03 & 12.02 & 15.01 & 15.15 & 17.01 & 18.74 & 14.95 & 14.7 & 17.66 \\
\hline GS & 5.55 & 9.76 & 8.97 & 5.81 & 11.12 & 9.59 & 5.35 & 1.83 & 3.08 & 4.9 & 9.69 & 8.43 & 8.08 & 12.79 & 11.13 \\
\hline PD & 4.29 & 0.65 & 2.33 & 3.71 & 0.39 & 2.33 & 0.28 & 0.51 & 1.83 & 4.7 & 0.73 & 2.9 & 1.22 & 0 & 1.56 \\
\hline $\mathrm{FF}$ & 0 & 0.4 & 0.34 & 0 & 0.28 & 0.31 & 0.1 & 0.04 & 0.49 & 0 & 0.32 & 0.31 & 0 & 0.23 & 0.31 \\
\hline PI & 1.56 & 2.19 & 2.15 & 0.64 & 1.77 & 1.65 & 0 & 0.24 & 0.38 & 0.87 & 2.28 & 2.45 & 0 & 1.04 & 0.55 \\
\hline $\mathrm{FP}$ & 5.84 & 3.93 & 5.29 & 6.14 & 3.75 & 5.43 & 11.31 & 8.29 & 8.8 & 6.34 & 4.11 & 6.07 & 5.65 & 3.11 & 4.46 \\
\hline Other & 5.62 & 5.73 & 6.85 & 5.83 & 5.84 & 7.06 & 3.09 & 2.93 & 4.07 & 6 & 6.96 & 8.28 & 5.33 & 4.25 & 5.32 \\
\hline ROA & 0.77 & 1.19 & 0.94 & 0.8 & 1.18 & 0.93 & 0.41 & 2.08 & 0.94 & 0.71 & 0.95 & 0.9 & 1.07 & 1.52 & 0.97 \\
\hline
\end{tabular}

Variables definitions (All variables are expressed in percentage except for total assets, which is expressed in billion pesos) Loans: ratio of net loans to total assets; Equity: ratio of equity to total assets; Deposits: ratio of total deposits to total assets; NII: ratio of non-interest income to total net operating income; FEE: ratio of fee-based income to total net operating income; BC: ratio of bank commissions and fees to total net operating income; SC: ratio of service charges to total net operating income; OC: ratio of other commissions and fees to total net operating income; TRAD: ratio of trading income to total net operating income; GS: ratio of income from trading government securities to total net operating income; PD: ratio of income from trading private debt/equity to total net operating income; FF: ratio of income from trading financial futures and other derivatives to total net operating income; PI: ratio of profit from sale of investments to total net operating income; FP: ratio of foreign exchange profit to total net operating income; Other: ratio of other non-interest income to total net operating income; ROA: return on average asset; ROE: return on average equity. 
Table 1B: Non-interest income components for Philippine universal and commercial banks over the 1999-2005 period (in \%)

\begin{tabular}{|c|c|c|c|c|c|c|c|c|}
\hline & Whole sample & Domestic banks & Foreign banks & Large banks & Medium-sized banks & Small banks & \multicolumn{2}{|c|}{ Universal banks Commercial banks } \\
\hline Fee-based activities & 38 & 32.70 & 47.70 & 35.70 & $\mathbf{3 6 . 5 0}$ & 40.80 & $\mathbf{3 3 . 4 0}$ & 40.60 \\
\hline Bank commissions & 28.60 & 21.10 & 42.20 & 23.50 & 19.80 & 38.50 & 24.10 & 31 \\
\hline Services charges & 61.40 & 69.30 & 47.20 & 64.50 & 78.30 & 46.10 & 69.50 & 57.10 \\
\hline Other commissions & 10 & 9.60 & 10.60 & 12 & 1.90 & 15.40 & 6.40 & 11.90 \\
\hline Trading activities & 45.30 & 47.80 & 40.80 & 41.30 & 47.20 & 46 & 46 & 44.90 \\
\hline Government securities & 30.60 & 41.90 & 13.90 & 31.20 & 43.10 & 21.40 & 36.90 & 27.60 \\
\hline Private debt/equity & 8.10 & 8.20 & 7.90 & 9 & 6.20 & 9 & 9.90 & 7.20 \\
\hline Financial futures & 2.50 & 2.40 & 2.80 & 4.90 & 4 & 0.60 & 2.50 & 2.60 \\
\hline Profit from sale of inv & 7.30 & 11.80 & 0.70 & 16.40 & 10.90 & 1.40 & 12.70 & 4.80 \\
\hline Foreign exchange profit & 51.50 & 35.70 & 74.70 & 38.50 & 35.80 & 67.60 & 38 & 57.80 \\
\hline Other & 16.70 & 19.50 & 11.50 & 23 & 16.30 & 13.20 & 20.60 & 14.50 \\
\hline
\end{tabular}

Variables definitions: Fee-based activities: ratio of fee-based income to non-interest income; Bank commission: ratio of bank commissions and fees to fee-based income ; Service charges: ratio of service charges to fee-based income; Other commissions: ratio of other commissions and fees to fee-based income; Trading activities: ratio of trading income to non-interest income; Government securities: ratio of income from trading government securities to trading income; Private debt/equity: ratio of income from trading private debt/equity to trading income; Financial futures: ratio of income from trading financial futures and other derivatives to trading income; Profit from sale of inv: ratio of profit from sale of investments to trading income; Other: ratio of other non-interest activities to non-interest income. 
Table 2A. Income diversification and profitability/risk for Philippine universal and commercial banks over the 1999-2005 period (H1)

\begin{tabular}{|c|c|c|c|c|c|c|c|c|c|c|c|c|}
\hline & \multirow{2}{*}{\multicolumn{4}{|c|}{ Fixed Effects Panel Regression }} & \multirow{2}{*}{\multicolumn{8}{|c|}{$\begin{array}{c}\text { Dynamic Panel Data Estimation } \\
\text { D }\end{array}$}} \\
\hline & & & & & Two-st & & & & & & & ist S.E. \\
\hline & ROA & SHROA & ROA & SHROA & ROA & SHROA & ROA & SHROA & ROA & SHROA & ROA & SHROA \\
\hline ROA (t-1) & & & & & $\begin{array}{c}0.345 * * * \\
(15.50)\end{array}$ & $\begin{array}{c}0.315 * * * \\
(4.79)\end{array}$ & $\begin{array}{c}0.371 * * * \\
(12.03)\end{array}$ & $\begin{array}{c}0.316^{* * * * *} \\
(4.49)\end{array}$ & $\begin{array}{c}0.345^{* * * *} \\
(3.55)\end{array}$ & $\begin{array}{c}0.315^{* * *} \\
(2.20)\end{array}$ & $\begin{array}{c}0.371 * * * \\
(3.55)\end{array}$ & $\begin{array}{l}0.316^{*} \\
(1.69)\end{array}$ \\
\hline FOCUS1 & $\begin{array}{l}-0.006 \\
(-0.54)\end{array}$ & $\begin{array}{l}-0.365 \\
(-0.27)\end{array}$ & & & $\begin{array}{c}-0.022 * * * * \\
(-4.47)\end{array}$ & $\begin{array}{c}-4.630 * * * \\
(-4.55)\end{array}$ & & & $\begin{array}{c}-0.0217 * * \\
(-2.45)\end{array}$ & $\begin{array}{c}-4.630 * * \\
(-2.41)\end{array}$ & & \\
\hline NII & $\begin{array}{c}0.017 * * \\
(2.62)\end{array}$ & $\begin{array}{c}2.040 * * * \\
(3.55)\end{array}$ & $\begin{array}{c}0.018 * * * \\
(3.03)\end{array}$ & $\begin{array}{c}2.114 * * * \\
(3.52)\end{array}$ & $\begin{array}{c}0.019 * * * * \\
(4.27)\end{array}$ & $\begin{array}{c}1.994 * * * \\
(2.97)\end{array}$ & $\begin{array}{c}0.022 * * * \\
(7.57)\end{array}$ & $\begin{array}{c}2.531 * * * * \\
(4.55)\end{array}$ & $\begin{array}{c}0.019 * * \\
(2.18)\end{array}$ & $\begin{array}{l}1.994 \\
(1.43)\end{array}$ & $\begin{array}{c}0.022 * * * \\
(2.76)\end{array}$ & $\begin{array}{l}2.531 \\
(1.58)\end{array}$ \\
\hline ASSET & $\begin{array}{c}0.026 * * \\
(2.30)\end{array}$ & $\begin{array}{c}2.814 * * \\
(2.62)\end{array}$ & $\begin{array}{c}0.026 * * \\
(2.33)\end{array}$ & $\begin{array}{c}2.847 * * \\
(2.61)\end{array}$ & $\begin{array}{c}-0.0071^{* * * *} \\
(-3.45)\end{array}$ & $\begin{array}{c}1.094 * * * * \\
(2.87)\end{array}$ & $\begin{array}{c}-0.005 * * \\
(-2.56)\end{array}$ & $\begin{array}{c}1.124 * * * * \\
(3.21)\end{array}$ & $\begin{array}{l}-0.007 \\
(-1.48)\end{array}$ & $\begin{array}{l}1.094 \\
(1.34)\end{array}$ & $\begin{array}{l}-0.005 \\
(-1.07)\end{array}$ & $\begin{array}{l}1.124 \\
(1.35)\end{array}$ \\
\hline GROWTH & $\begin{array}{c}-0.005 * * * \\
(-3.28)\end{array}$ & $\begin{array}{l}-0.098 \\
(-0.94)\end{array}$ & $\begin{array}{c}-0.005 * * * \\
(-3.32)\end{array}$ & $\begin{array}{l}-0.103 \\
(-1.05)\end{array}$ & $\begin{array}{l}-0.001 \\
(-0.53)\end{array}$ & $\begin{array}{c}-0.661^{*} \\
(-1.68)\end{array}$ & $\begin{array}{l}-0.002 \\
(-0.92)\end{array}$ & $\begin{array}{c}-0.654^{*} \\
(-1.65)\end{array}$ & $\begin{array}{l}-0.001 \\
(-0.16)\end{array}$ & $\begin{array}{l}-0.661 \\
(-0.57)\end{array}$ & $\begin{array}{l}-0.002 \\
(-0.30)\end{array}$ & $\begin{array}{l}-0.654 \\
(-0.52)\end{array}$ \\
\hline EQUITY & $\begin{array}{l}0.034 \\
(0.92)\end{array}$ & $\begin{array}{l}5.612 * \\
(1.74)\end{array}$ & $\begin{array}{l}0.034 \\
(0.93)\end{array}$ & $\begin{array}{l}5.611 * \\
(1.76)\end{array}$ & $\begin{array}{c}-0.031 \text { **** } \\
(-3.22)\end{array}$ & $\begin{array}{l}-2.624 \\
(-1.40)\end{array}$ & $\begin{array}{c}-0.029^{* * * *} \\
(-2.93)\end{array}$ & $\begin{array}{c}-2.999 * \\
(-1.77)\end{array}$ & $\begin{array}{l}-0.031 \\
(-1.33)\end{array}$ & $\begin{array}{l}-2.624 \\
(-0.45)\end{array}$ & $\begin{array}{l}-0.029 \\
(-1.25)\end{array}$ & $\begin{array}{l}-2.999 \\
(-0.50)\end{array}$ \\
\hline LOANS & $\begin{array}{c}0.025^{* * *} \\
(2.62)\end{array}$ & $\begin{array}{l}1.090 \\
(1.48)\end{array}$ & $\begin{array}{c}0.024 * * \\
(2.66)\end{array}$ & $\begin{array}{l}1.064 \\
(1.52)\end{array}$ & $\begin{array}{c}-0.017 * * * \\
(-8.34)\end{array}$ & $\begin{array}{l}-0.099 \\
(-0.16)\end{array}$ & $\begin{array}{c}-0.021 * * * * \\
(-10.45)\end{array}$ & $\begin{array}{l}-0.763 \\
(-1.08)\end{array}$ & $\begin{array}{c}-0.017 * \\
(-1.93)\end{array}$ & $\begin{array}{l}-0.099 \\
(-0.06)\end{array}$ & $\begin{array}{c}-0.021 * * \\
(-2.57)\end{array}$ & $\begin{array}{l}-0.763 \\
(-0.39)\end{array}$ \\
\hline GDP & $\begin{array}{c}0.024 * * \\
(2.65)\end{array}$ & $\begin{array}{c}4.000^{* * * *} \\
(4.25)\end{array}$ & $\begin{array}{c}0.024 * * \\
(2.66)\end{array}$ & $\begin{array}{c}4.007 * * * * \\
(4.30)\end{array}$ & $\begin{array}{c}0.015^{* * * *} \\
(3.53)\end{array}$ & $\begin{array}{c}1.447 * * * \\
(2.64)\end{array}$ & $\begin{array}{c}0.015 * * * \\
(3.75)\end{array}$ & $\begin{array}{c}1.599 * * * * \\
(2.67)\end{array}$ & $\begin{array}{c}0.015 * \\
(1.65)\end{array}$ & $\begin{array}{l}1.447 \\
(1.02)\end{array}$ & $\begin{array}{c}0.015^{*} \\
(1.71)\end{array}$ & $\begin{array}{l}1.599 \\
(0.99)\end{array}$ \\
\hline Constant & $\begin{array}{c}-0.449 * * * * \\
(-4.05)\end{array}$ & $\begin{array}{c}-57.15^{* * * *} \\
(-6.00)\end{array}$ & $\begin{array}{c}-0.459 * * * \\
(-4.08) \\
\end{array}$ & $\begin{array}{c}-57.77 * * * * \\
(-6.01) \\
\end{array}$ & $\begin{array}{l}-0.002 \\
(-0.05)\end{array}$ & $\begin{array}{c}-17.67 * * * * \\
(-3.47)\end{array}$ & $\begin{array}{l}-0.035 \\
(-0.99)\end{array}$ & $\begin{array}{c}-21.57^{* * * * *} \\
(-4.29)\end{array}$ & $\begin{array}{l}-0.002 \\
(-0.02) \\
\end{array}$ & $\begin{array}{l}-17.67 \\
(-1.37)\end{array}$ & $\begin{array}{l}-0.035 \\
(-0.49)\end{array}$ & $\begin{array}{l}-21.57 \\
-1.59) \\
\end{array}$ \\
\hline $\begin{array}{c}\text { R2 } \\
\text { OBS }\end{array}$ & $\begin{array}{l}0.31 \\
218\end{array}$ & $\begin{array}{l}0.26 \\
218\end{array}$ & $\begin{array}{l}0.31 \\
218\end{array}$ & $\begin{array}{l}0.26 \\
218\end{array}$ & 187 & 187 & 187 & 187 & 187 & 187 & 187 & 187 \\
\hline
\end{tabular}

ROA: return on average assets; SHROA: ratio of return on average assets to standard deviation of ROA (annual data); FOCUS1= focus index based on a two part operating income breakdown- noninterest income and interest income; NII: ratio of non-interest income to total operating income; Asset: logarithm of total assets; Growth: average asset growth; Equity: ratio of equity to total assets; Loans: ratio of net loans to total assets; GDP: logarithm of the gross domestic product.

Table 2B Estimated impact of a change in share of non-interest income on profitability and risk-adjusted profitability

\begin{tabular}{|c|c|c|c|c|c|c|c|c|}
\hline \multirow[b]{3}{*}{ NII } & \multicolumn{4}{|c|}{ ROA } & \multicolumn{4}{|c|}{ SHROA } \\
\hline & \multicolumn{2}{|c|}{ Fixed Effect } & \multicolumn{2}{|c|}{ Two-Step Robust S.E. } & \multicolumn{2}{|c|}{$\begin{array}{ll}\text { Fixed Effects } \\
\end{array}$} & \multicolumn{2}{|c|}{$\begin{array}{c}\text { Two-Step Robust S.E. } \\
\end{array}$} \\
\hline & Indirect & $\mathrm{Net}$ & Indirect & $\mathrm{Net}$ & Indirect & $\mathrm{Net}$ & Indirect & $\mathrm{Net}$ \\
\hline $10^{\text {th }}$ & $\begin{array}{c}0.007 \\
(0.014)\end{array}$ & $\begin{array}{l}0.024 * \\
(0.012)\end{array}$ & $\begin{array}{c}0.028^{* * *} \\
(0.011)\end{array}$ & $\begin{array}{c}0.046^{* * * * *} \\
(0.012)\end{array}$ & $\begin{array}{c}0.463 \\
(1.706)\end{array}$ & $\begin{array}{l}2.503 \\
(1.72)\end{array}$ & $\begin{array}{l}5.88 * * \\
(2.44)\end{array}$ & $\begin{array}{c}7.87 * * * * \\
(1.74)\end{array}$ \\
\hline $25^{\text {th }}$ & 0.006 & $0.022 * *$ & $0.021 * *$ & $\begin{array}{c}0.039^{* * * *} \\
(0.010)\end{array}$ & $\begin{array}{c}0.35 \\
(1.28)\end{array}$ & $\begin{array}{c}2.39^{*} \\
(1.331)\end{array}$ & $\begin{array}{l}4.42 * * \\
(1.83)\end{array}$ & $\begin{array}{c}6.41 * * * \\
(1.28)\end{array}$ \\
\hline $50^{\text {th }}$ & $\begin{array}{c}0.004 \\
(0.007)\end{array}$ & $\begin{array}{l}0.02 * * * * \\
(0.007)\end{array}$ & $\begin{array}{c}0.0132^{* * *} \\
(0.005)\end{array}$ & $\begin{array}{c}0.032 * * * * \\
(0.009)\end{array}$ & $\begin{array}{c}0.23 \\
(0.846)\end{array}$ & $\begin{array}{c}2.270^{* * *} \\
(0.95)\end{array}$ & $2.83^{* *}$ & $\begin{array}{c}4.82^{* * * *} \\
(099)\end{array}$ \\
\hline $75^{\text {th }}$ & $\begin{array}{c}0.001 \\
(0.003)\end{array}$ & $\begin{array}{c}0.018 * * * * \\
(0.006)\end{array}$ & $\begin{array}{c}(0.005) \\
0.005 * * \\
(0.002)\end{array}$ & $\begin{array}{c}(0.024 * * * \\
0.008)\end{array}$ & $\begin{array}{c}(.040) \\
0.09 \\
(0.333)\end{array}$ & $\begin{array}{l}(0.93)) \\
2.13^{* * * *} \\
(0.619)\end{array}$ & $\begin{array}{c}1.07 * * * \\
(0.44)\end{array}$ & $\begin{array}{c}\left(\begin{array}{c}(9.99) \\
(1.12)\end{array}\right.\end{array}$ \\
\hline $90^{\text {th }}$ & $\begin{array}{l}-0.001 \\
(0.001)\end{array}$ & $\begin{array}{c}0.016 \text { *** } \\
0.007\end{array}$ & $\begin{array}{c}-0.007 * * \\
(0.003)\end{array}$ & $\begin{array}{c}0.012 \\
(0.010)\end{array}$ & $\begin{array}{c}-0.059 \\
(0.216)\end{array}$ & $\begin{array}{c}1.981^{* * * * *} \\
(0.642)\end{array}$ & $\begin{array}{c}-1.50^{* *} \\
(0.62)\end{array}$ & $\begin{array}{c}0.49 \\
(1.89)\end{array}$ \\
\hline
\end{tabular}


Table 3A. Income diversification and profitability of Philippine universal and commercial banks over the 1999-2005 period: impact of differences in bank ownership type (H1a)

\begin{tabular}{|c|c|c|c|c|c|c|c|c|}
\hline & \multicolumn{4}{|c|}{ "DOMESTIC BANKS } & \multicolumn{4}{|c|}{ FOREIGN BANKS } \\
\hline & ROA & SHROA & ROA & SHROA & ROA & SHROA & ROA & SHROA \\
\hline FOCUS1 & $\begin{array}{l}-0.001 \\
(-0.14)\end{array}$ & $\begin{array}{l}-0.151 \\
(-0.10)\end{array}$ & & & $\begin{array}{l}0.075 \\
(0.94)\end{array}$ & $\begin{array}{l}4.971 \\
(1.04)\end{array}$ & & \\
\hline NII & $\begin{array}{l}0.006 \\
(1.43)\end{array}$ & $\begin{array}{c}1.585 * * \\
(2.44)\end{array}$ & $\begin{array}{l}0.006 \\
(1.41)\end{array}$ & $\begin{array}{c}1.606 * * \\
(2.30)\end{array}$ & $\begin{array}{c}0.082 * \\
(1.87)\end{array}$ & $\begin{array}{c}5.550 * * \\
(2.37)\end{array}$ & $\begin{array}{c}0.051 * * * \\
(2.95)\end{array}$ & $\begin{array}{c}3.511 * * * \\
(3.19)\end{array}$ \\
\hline ASSET & $\begin{array}{l}0.012 \\
(1.08)\end{array}$ & $\begin{array}{l}2.121 \\
(1.49)\end{array}$ & $\begin{array}{l}0.012 \\
(1.05)\end{array}$ & $\begin{array}{l}2.139 \\
(1.47)\end{array}$ & $\begin{array}{c}0.045 * \\
(1.85)\end{array}$ & $\begin{array}{c}3.736 * * \\
(2.37)\end{array}$ & $\begin{array}{c}0.042 * \\
(1.85)\end{array}$ & $\begin{array}{c}3.523 * * \\
(2.23)\end{array}$ \\
\hline GROWTH & $\begin{array}{c}0.005^{*} \\
(1.80)\end{array}$ & $\begin{array}{l}0.208 \\
(0.55)\end{array}$ & $\begin{array}{c}0.005^{*} \\
(1.82)\end{array}$ & $\begin{array}{l}0.208 \\
(0.55)\end{array}$ & $\begin{array}{c}-0.006^{* * *} \\
(-5.46)\end{array}$ & $\begin{array}{l}-0.097 \\
(-0.88)\end{array}$ & $\begin{array}{c}-0.006 * * * \\
(-5.49)\end{array}$ & $\begin{array}{l}-0.057 \\
(-0.52)\end{array}$ \\
\hline EQUITY & $\begin{array}{l}0.021 \\
(0.64)\end{array}$ & $\begin{array}{l}5.351 \\
(1.34)\end{array}$ & $\begin{array}{l}0.021 \\
(0.65)\end{array}$ & $\begin{array}{l}5.355 \\
(1.35)\end{array}$ & $\begin{array}{l}0.107 \\
(0.98)\end{array}$ & $\begin{array}{l}10.43 \\
(1.36)\end{array}$ & $\begin{array}{l}0.090 \\
(0.86)\end{array}$ & $\begin{array}{l}9.316 \\
(1.23)\end{array}$ \\
\hline LOANS & $\begin{array}{l}-0.003 \\
(-0.20)\end{array}$ & $\begin{array}{l}-0.676 \\
(-0.51)\end{array}$ & $\begin{array}{l}-0.003 \\
(-0.22)\end{array}$ & $\begin{array}{l}-0.690 \\
(-0.56)\end{array}$ & $\begin{array}{c}0.025 * \\
(1.79)\end{array}$ & $\begin{array}{c}2.004 * \\
(1.99)\end{array}$ & $\begin{array}{c}0.030 * * \\
(2.47)\end{array}$ & $\begin{array}{c}2.279 * * \\
(2.31)\end{array}$ \\
\hline GDP & $\begin{array}{c}0.015^{* *} \\
(2.11)\end{array}$ & $\begin{array}{c}4.406^{* * * *} \\
(4.05)\end{array}$ & $\begin{array}{c}0.015^{* *} \\
(2.13)\end{array}$ & $\begin{array}{c}4.409 * * * \\
(4.11)\end{array}$ & $\begin{array}{l}0.027 \\
(1.37)\end{array}$ & $\begin{array}{l}2.565 \\
(1.41)\end{array}$ & $\begin{array}{l}0.028 \\
(1.56)\end{array}$ & $\begin{array}{l}2.629 \\
(1.50)\end{array}$ \\
\hline Constant & $\begin{array}{c}-0.229 * * \\
(-2.53)\end{array}$ & $\begin{array}{c}-51.93 * * * \\
(-4.18)\end{array}$ & $\begin{array}{c}-0.232 * * \\
(-2.34)\end{array}$ & $\begin{array}{c}-52.23 * * * \\
(-4.07)\end{array}$ & $\begin{array}{c}-0.732 * * * \\
(-3.13)\end{array}$ & $\begin{array}{c}-61.21 * * * \\
(-4.45)\end{array}$ & $\begin{array}{c}-0.653 * * * \\
(-3.16)\end{array}$ & $\begin{array}{c}-55.95 * * * \\
(-4.59)\end{array}$ \\
\hline R-square & 0.17 & 0.24 & 0.17 & 0.24 & 0.55 & 0.40 & 0.53 & 0.39 \\
\hline OBS & 140 & 140 & 140 & 140 & 78 & 78 & 78 & 78 \\
\hline Wald Test & 1.04 & $2.98^{*}$ & & & $4.4^{* *}$ & $3.99 * *$ & & \\
\hline
\end{tabular}

Table 3B: Estimated impact of an increased share in non-interest income: impact of differences in bank ownership type

\begin{tabular}{|c|c|c|c|c|c|c|}
\hline \multirow[b]{3}{*}{ NII Percentiles } & \multicolumn{2}{|c|}{ DOMESTIC } & \multicolumn{4}{|c|}{ FOREIGN } \\
\hline & \multicolumn{2}{|c|}{ SHROA } & \multicolumn{2}{|c|}{ ROA } & \multicolumn{2}{|c|}{ SHROA } \\
\hline & Indirect & Net & Indirect & Net & Indirect & $\mathrm{Net}$ \\
\hline $10^{\text {th }}$ & $\begin{array}{c}0.198 \\
(2.063)\end{array}$ & $\begin{array}{c}1.784 \\
(2.218)\end{array}$ & $\begin{array}{l}-0.086 \\
(0.091)\end{array}$ & $\begin{array}{c}-0.004 \\
(0.053)\end{array}$ & $\begin{array}{c}-5.688 \\
(5.45)\end{array}$ & $\begin{array}{l}-0.138 \\
(3.78)\end{array}$ \\
\hline $25^{\text {th }}$ & $\begin{array}{c}0.149 \\
(1.543)\end{array}$ & $\begin{array}{c}1.734 \\
(1.728)\end{array}$ & $\begin{array}{l}-0.069 \\
(0.073)\end{array}$ & $\begin{array}{c}0.013 \\
(0.036)\end{array}$ & $\begin{array}{l}-4.558 \\
(4.367)\end{array}$ & $\begin{array}{c}0.993 \\
(2.797)\end{array}$ \\
\hline $50^{\text {th }}$ & $\begin{array}{c}0.095 \\
(0.988)\end{array}$ & $\begin{array}{c}1.68 \\
(1.230)\end{array}$ & $\begin{array}{l}-0.046 \\
(0.049)\end{array}$ & $\begin{array}{l}0.036^{*} \\
(0.017)\end{array}$ & $\begin{array}{l}-3.066 \\
(2.938)\end{array}$ & $\begin{array}{c}2.484 \\
(1.693)\end{array}$ \\
\hline $75^{\text {th }}$ & $\begin{array}{c}0.041 \\
(0.426)\end{array}$ & $\begin{array}{l}1.626^{*} \\
(0.809)\end{array}$ & $\begin{array}{l}-0.017 \\
(0.018)\end{array}$ & $\begin{array}{c}0.065^{* *} \\
(0.028)\end{array}$ & $\begin{array}{l}-1.099 \\
(1.053)\end{array}$ & $\begin{array}{c}4.452 * * \\
(1.604)\end{array}$ \\
\hline $90^{\text {th }}$ & $\begin{array}{c}-0.055 \\
(0.571) \\
\end{array}$ & $\begin{array}{c}1.53^{*} \\
(0.826) \\
\end{array}$ & $\begin{array}{c}0.010 \\
(0.010)\end{array}$ & $\begin{array}{c}0.091 \\
(0.053) \\
\end{array}$ & $\begin{array}{r}0.639 \\
(0.612) \\
\end{array}$ & $\begin{array}{c}6.189 * * \\
(2.868) \\
\end{array}$ \\
\hline
\end{tabular}


Table 4. Product mixes within non-interest activities and profitability/risk for Philippine universal and commercial banks over the 1999-2005 period (H2, model 2)

\begin{tabular}{|c|c|c|c|c|c|c|c|c|c|c|c|c|}
\hline & \multirow{2}{*}{\multicolumn{4}{|c|}{ Fixed Effects Panel Regression }} & \multicolumn{8}{|c|}{ Dynamic Panel Data Estimation } \\
\hline & & & & & \multicolumn{2}{|c|}{ Two Step GMM S.E. } & \multicolumn{2}{|c|}{ Two Step Robust S.E. } & \multicolumn{2}{|c|}{ Two Step GMM S.E. } & \multicolumn{2}{|c|}{ Two Step Robust S.E. } \\
\hline & ROA & SHROA & ROA & SHROA & ROA & SHROA & ROA & SHROA & ROA & SHROA & ROA & SHROA \\
\hline ROA(t-1) & & & & & $\begin{array}{c}0.260 * * * \\
(5.66)\end{array}$ & $\begin{array}{c}0.130 * * * \\
(2.74)\end{array}$ & $\begin{array}{c}0.260^{* *} \\
(2.32)\end{array}$ & $\begin{array}{l}0.132 \\
(1.31)\end{array}$ & $\begin{array}{c}0.3^{* * * *} \\
(6.16)\end{array}$ & $\begin{array}{c}0.188 * * * \\
(3.28)\end{array}$ & $\begin{array}{c}0.25 * * \\
(1.99)\end{array}$ & $\begin{array}{c}0.188^{*} \\
(1.70)\end{array}$ \\
\hline FOCUS2 & $\begin{array}{l}-0.004 \\
(-0.26)\end{array}$ & $\begin{array}{l}-0.337 \\
(-0.19)\end{array}$ & & & $\begin{array}{c}-0.014 * * \\
(-2.15)\end{array}$ & $\begin{array}{c}-2.120 * * * \\
(-2.60)\end{array}$ & $\begin{array}{l}-0.014 \\
(-0.65)\end{array}$ & $\begin{array}{l}-2.123 \\
(-1.07)\end{array}$ & & & & \\
\hline FEE & $\begin{array}{l}0.005 \\
(0.35)\end{array}$ & $\begin{array}{l}-0.441 \\
(-0.31)\end{array}$ & $\begin{array}{l}0.008 \\
(0.63)\end{array}$ & $\begin{array}{l}-0.260 \\
(-0.26)\end{array}$ & $\begin{array}{c}-0.023 * * * \\
(-4.11)\end{array}$ & $\begin{array}{c}-2.599^{*} \\
(-1.82)\end{array}$ & $\begin{array}{l}-0.023 \\
(-0.99)\end{array}$ & $\begin{array}{l}-2.599 \\
(-0.85)\end{array}$ & $\begin{array}{c}-.01 * * * \\
(-3.64)\end{array}$ & $\begin{array}{l}-2.157 \\
(-1.53)\end{array}$ & $\begin{array}{l}-0.012 \\
(-0.72)\end{array}$ & $\begin{array}{l}-2.157 \\
(-0.76)\end{array}$ \\
\hline TRAD & $\begin{array}{l}0.023 \\
(1.67)\end{array}$ & $\begin{array}{l}2.9 * * * \\
(2.80)\end{array}$ & $\begin{array}{c}.030 * * * * \\
(2.90)\end{array}$ & $\begin{array}{c}3.161 * * * \\
(4.80)\end{array}$ & $\begin{array}{c}0.017 * * * \\
(4.71)\end{array}$ & $\begin{array}{c}1.610^{* * * *} \\
(3.03)\end{array}$ & $\begin{array}{l}0.017 \\
(1.10)\end{array}$ & $\begin{array}{l}1.612 \\
(1.02)\end{array}$ & $\begin{array}{l}.02 * * * \\
(9.37)\end{array}$ & $\begin{array}{c}2.148^{* * * *} \\
(5.47)\end{array}$ & $\begin{array}{l}0.02 * * \\
(2.39)\end{array}$ & $\begin{array}{c}2.148^{* * *} \\
(2.03)\end{array}$ \\
\hline Other & $\begin{array}{l}-0.020 \\
(-0.93)\end{array}$ & $\begin{array}{l}-2.025 \\
(-0.82)\end{array}$ & $\begin{array}{l}-0.016 \\
(-0.85)\end{array}$ & $\begin{array}{l}-1.724 \\
(-0.81)\end{array}$ & $\begin{array}{l}-0.007 \\
(-0.61)\end{array}$ & $\begin{array}{c}-4.970 * * * \\
(-4.71)\end{array}$ & $\begin{array}{l}-0.007 \\
(-0.31)\end{array}$ & $\begin{array}{l}-4.970 \\
(-1.34)\end{array}$ & $\begin{array}{l}-0.0152 \\
(-1.21)\end{array}$ & $\begin{array}{c}-5.06 * * * \\
(-3.96)\end{array}$ & $\begin{array}{l}-0.015 \\
(-0.58)\end{array}$ & $\begin{array}{l}-5.058 \\
(-1.35)\end{array}$ \\
\hline ASSET & $\begin{array}{l}0.02^{* *} \\
(2.49)\end{array}$ & $\begin{array}{l}2.58^{* * *} \\
(2.68)\end{array}$ & $\begin{array}{l}0.03 * * \\
(2.52)\end{array}$ & $\begin{array}{c}2.600 * * \\
(2.68)\end{array}$ & $\begin{array}{c}-0.008^{* * * *} \\
(-3.38)\end{array}$ & $\begin{array}{c}1.550 * * * \\
(4.14)\end{array}$ & $\begin{array}{l}-0.008 \\
(-1.57)\end{array}$ & $\begin{array}{c}1.553^{* * *} \\
(2.14)\end{array}$ & $\begin{array}{l}-0.004 \\
(-1.49)\end{array}$ & $\begin{array}{c}1.113^{* * * *} \\
(4.06)\end{array}$ & $\begin{array}{l}-0.004 \\
(-0.67)\end{array}$ & $\begin{array}{l}1.113 \\
(1.59)\end{array}$ \\
\hline GROWTH & $\begin{array}{c}-0.01 * * * \\
(-3.77)\end{array}$ & $\begin{array}{l}-0.186^{*} \\
(-1.79)\end{array}$ & $\begin{array}{l}-.01 * * * \\
(-3.78)\end{array}$ & $\begin{array}{c}-0.188^{*} \\
(-1.85)\end{array}$ & $\begin{array}{r}0.0005 \\
(0.30)\end{array}$ & $\begin{array}{c}-0.7 * * * \\
(-3.47)\end{array}$ & $\begin{array}{l}0.0005 \\
(0.09)\end{array}$ & $\begin{array}{l}-0.695 \\
(-1.60)\end{array}$ & $\begin{array}{l}-0.0023 \\
(-1.35)\end{array}$ & $\begin{array}{c}-1.05 * * * \\
(-4.28)\end{array}$ & $\begin{array}{l}-0.002 \\
(-0.37)\end{array}$ & $\begin{array}{l}-1.053 \\
(-1.52)\end{array}$ \\
\hline EQUITY & $\begin{array}{l}0.023 \\
(0.68)\end{array}$ & $\begin{array}{l}4.636 \\
(1.46)\end{array}$ & $\begin{array}{l}0.023 \\
(0.69)\end{array}$ & $\begin{array}{l}4.623 \\
(1.48)\end{array}$ & $\begin{array}{c}-0.037 * * * * \\
(-4.50)\end{array}$ & $\begin{array}{c}-4.157 * * \\
(-2.13)\end{array}$ & $\begin{array}{l}-0.037 \\
(-1.37)\end{array}$ & $\begin{array}{l}-4.157 \\
(-1.37)\end{array}$ & $\begin{array}{c}-.040 * * * * \\
(-5.62)\end{array}$ & $\begin{array}{c}-8.69 * * * \\
(-5.73)\end{array}$ & $\begin{array}{l}-0.035 \\
(-1.30)\end{array}$ & $\begin{array}{c}-8.70^{* * * *} \\
(-2.66)\end{array}$ \\
\hline LOANS & $\begin{array}{c}0.028^{* * *} \\
(2.42)\end{array}$ & $\begin{array}{l}1.140 \\
(1.45)\end{array}$ & $\begin{array}{c}0.030 * * \\
(2.44)\end{array}$ & $\begin{array}{l}1.125 \\
(1.49)\end{array}$ & $\begin{array}{c}-0.016 * * * * \\
(-6.38)\end{array}$ & $\begin{array}{l}-0.044 \\
(-0.10)\end{array}$ & $\begin{array}{c}-0.016^{*} \\
(-1.76)\end{array}$ & $\begin{array}{l}-0.044 \\
(-0.03)\end{array}$ & $\begin{array}{c}-.020 * * * * \\
(-6.49)\end{array}$ & $\begin{array}{c}0.062 \\
(0.15)\end{array}$ & $\begin{array}{c}-0.018^{*} \\
(-1.78)\end{array}$ & $\begin{array}{l}0.062 \\
(0.04)\end{array}$ \\
\hline GDP & $\begin{array}{c}0.029 * * * \\
(3.09)\end{array}$ & $\begin{array}{l}4.6^{* * * *} \\
(4.49)\end{array}$ & $\begin{array}{c}.030^{* * * *} \\
(3.09)\end{array}$ & $\begin{array}{c}4.561 * * * \\
(4.55)\end{array}$ & $\begin{array}{c}0.024 * * * \\
(6.27)\end{array}$ & $\begin{array}{c}3.09 * * * \\
(5.26)\end{array}$ & $\begin{array}{c}0.024^{* *} \\
(2.27)\end{array}$ & $\begin{array}{l}3.09 * * \\
(2.15)\end{array}$ & $\begin{array}{l}.02 * * * \\
(4.72)\end{array}$ & $\begin{array}{c}2.976 * * * \\
(4.86)\end{array}$ & $\begin{array}{l}0.02 * \\
(1.68)\end{array}$ & $\begin{array}{c}2.976^{* * *} \\
(2.17)\end{array}$ \\
\hline Constant & $\begin{array}{c}-0.46^{* * * *} \\
(-4.42) \\
\end{array}$ & $\begin{array}{l}-58 * * * \\
(-6.66) \\
\end{array}$ & $\begin{array}{c}-0.500^{* * * *} \\
(-4.43) \\
\end{array}$ & $\begin{array}{c}-58.6 * * * \\
(-6.76) \\
\end{array}$ & $\begin{array}{c}-0.046^{* * *} * \\
(-3.16) \\
\end{array}$ & $\begin{array}{c}-33.90 * * * * \\
(-7.39) \\
\end{array}$ & $\begin{array}{l}-0.046 \\
(-0.61) \\
\end{array}$ & $\begin{array}{c}-33.90^{* * * *} \\
(-2.87) \\
\end{array}$ & $\begin{array}{c}-0.10 * * * * \\
(-5.99) \\
\end{array}$ & $\begin{array}{c}-29.2 * * * \\
(-10.20) \\
\end{array}$ & $\begin{array}{l}-0.068 \\
(-0.92) \\
\end{array}$ & $\begin{array}{l}-29 * * * \\
(-3.43)\end{array}$ \\
\hline R-square & 0.37 & 0.34 & 0.36 & 0.34 & & & & & & & & \\
\hline OBS & 212 & 212 & 212 & 212 & 181 & 181 & 181 & 181 & 181 & 181 & 181 & 181 \\
\hline Wald test & $3.77 * *$ & $8.64 * * *$ & & & $180.15^{* * *}$ & $197 * * *$ & $12.77 * *$ & $32.1 * * *$ & & & & \\
\hline $\begin{array}{l}\text { Sargan test } \\
\text { Test for autocorr }\end{array}$ & & & & & 0.9 & 0.9 & & & 0.9 & 0.9 & & \\
\hline M $1: 1^{\text {st }}$ order & & & & & 0.03 & 0.01 & 0.05 & 0.01 & 0.03 & 0.01 & 0.05 & 0.02 \\
\hline $\begin{array}{l}\text { M2: } 2^{\text {nd }} \\
\text { orderPartial coeff: }\end{array}$ & & & & & 0.17 & 0.79 & 0.21 & 0.69 & 0.16 & 0.80 & 0.21 & 0.80 \\
\hline FeeBased & 0.004 & -0.531 & & & $-0.027 * * *$ & $-3.170 * *$ & -0.027 & -3.170 & & & & \\
\hline Trading & 0.022 & $2.886^{*}$ & & & $0.013 * *$ & 0.894 & 0.013 & 0.894 & & & & \\
\hline Other & -0.020 & -2.064 & & & -0.009 & -5.229 & -0.009 & -5.229 & & & & \\
\hline
\end{tabular}

$* * *, * *$ and $*$ indicate significance at the $1 \%, 5 \%$ and $10 \%$ levels, respectively. T-statistics are corrected for heteroskedasticity following White's methodology for the fixed effects panel regression. Variable definitions ROA: return on average assets; SHROA: ratio of return on average assets to standard deviation of ROA (annual data); FOCUS2: focus index based on a four-part operating income breakdown- fee based income, trading income and other non-interest income; FEE: ratio of fee-based income to total operating income; TRAD: ratio of trading income to total operating income; Other: ratio of other non-interest income to total operating income; Asset: logarithm of total assets; Growth: average asset growth; Equity: ratio of equity to total assets; Loans: ratio of net loans to total assets; GDP: logarithm of the gross domestic product. 
Table 5. Aggregate Data on the Compliance with Micro, Small and Medium Enterprises Credi t Required under R.A. NO. 6977, as Amended by R.A.s Nos 8289 and 9501 of Universal and Commercial Banks (UKBs) in the Philippines from 1999 to 2005 (in million pesos)

\begin{tabular}{|c|c|c|c|c|c|c|c|}
\hline & $\begin{array}{c}\text { December } \\
2005\end{array}$ & $\begin{array}{c}\text { December } \\
2004\end{array}$ & $\begin{array}{c}\text { December } \\
2003\end{array}$ & $\begin{array}{c}\text { December } \\
2002\end{array}$ & $\begin{array}{c}\text { December } \\
2001\end{array}$ & $\begin{array}{c}\text { December } \\
2000\end{array}$ & $\begin{array}{c}\text { December } \\
1999\end{array}$ \\
\hline \multicolumn{8}{|c|}{ MICRO, SMALL AND MEDIUM ENTERPRISES CREDIT (6\% \& $2 \%)$} \\
\hline Direct Compliance for MSMEs & 154275 & 163204 & 163304 & 183486 & 184862 & 180951 & 174959 \\
\hline Alternative/Indirect Compliance for MSMEs & 14277 & 14489 & 13175 & 38620 & 7465 & 8622 & 27699 \\
\hline Funds Set Aside for MSMEs & 11946 & 11003 & 10992 & 9909 & 7706 & 6150 & 5181 \\
\hline Total Compliance for MSMEs & 180498 & 188696 & 187471 & 232015 & 200033 & 195723 & 207839 \\
\hline Total Loan Portfolio Net of Exclusions & 912867 & 903565 & 888287 & 798264 & 857073 & 911968 & 902839 \\
\hline Percentage of Compliance for MSMEs & 19.77 & 20.88 & 21.10 & 29.06 & 23.34 & 21.46 & 23.02 \\
\hline Percentage of Compliance for MSMEs (direct) & 16.90 & 18.06 & 18.38 & 22.99 & 21.57 & 19.84 & 19.38 \\
\hline Percentage of Compliance for MSMEs (alternative) & 1.56 & 1.60 & 1.48 & 4.84 & 0.87 & 0.95 & 3.07 \\
\hline \multicolumn{8}{|l|}{ MICRO AND SMALL ENTERPRISES CREDIT (6\%) } \\
\hline Direct Compliance for MSEs & 67583 & 72854 & 75632 & 103272 & 112892 & 95873 & 105491 \\
\hline Alternative/Indirect Compliance for MSEs & 7311 & 7689 & 6565 & 18811 & 3849 & 4630 & 14068 \\
\hline Funds Set Aside for MSEs & 9444 & 8451 & 8323 & 7518 & 5971 & 4681 & 4040 \\
\hline Total Compliance for MSEs & 84337 & 88994 & 90520 & 129600 & 122712 & 105184 & 123599 \\
\hline Total Loan Portfolio Net of Exclusions & 912867 & 903565 & 888287 & 798264 & 857073 & 911968 & 902839 \\
\hline Percentage of Compliance for MSEs & 9.24 & 9.85 & 10.19 & 16.24 & 14.32 & 11.53 & 13.69 \\
\hline Percentage of Compliance for MSEs (direct) & 7.40 & 8.06 & 8.51 & 12.94 & 13.17 & 10.51 & 11.68 \\
\hline Percentage of Compliance for MSEs (alternative) & 0.80 & 0.85 & 0.74 & 2.36 & 0.45 & 0.51 & 1.56 \\
\hline \multicolumn{8}{|l|}{ MEDIUM ENTERPRISES CREDIT $(2 \%)$} \\
\hline Direct Compliance for MEs & 86693 & 90350 & 87672 & 80214 & 71970 & 85078 & 69468 \\
\hline Alternative/Indirect Compliance for MEs & 6966 & 6800 & 6610 & 19810 & 3616 & 3992 & 13631 \\
\hline Funds Set Aside for MEs & 2503 & 2552 & 2669 & 2392 & 1735 & 1469 & 1141 \\
\hline Total Compliance for MEs & 96161 & 99702 & 96950 & 102415 & 77321 & 90539 & 84240 \\
\hline Total Loan Portfolio Net of Exclusions & 912867 & 903565 & 888287 & 798264 & 857073 & 911968 & 902839 \\
\hline Percentage of Compliance for MEs & 10.53 & 11.03 & 10.91 & 12.83 & 9.02 & 9.93 & 9.33 \\
\hline Percentage of Compliance for MEs (direct) & 9.50 & 10.00 & 9.87 & 10.05 & 8.40 & 9.33 & 7.69 \\
\hline Percentage of Compliance for MEs (alternative) & 0.76 & 0.75 & 0.74 & 2.48 & 0.42 & 0.44 & 1.51 \\
\hline
\end{tabular}


Table 6A. The effect of income diversification on profitability and risk-adjusted profitability according to compliance with the mandated credit program, Magna Carta for Small Firms

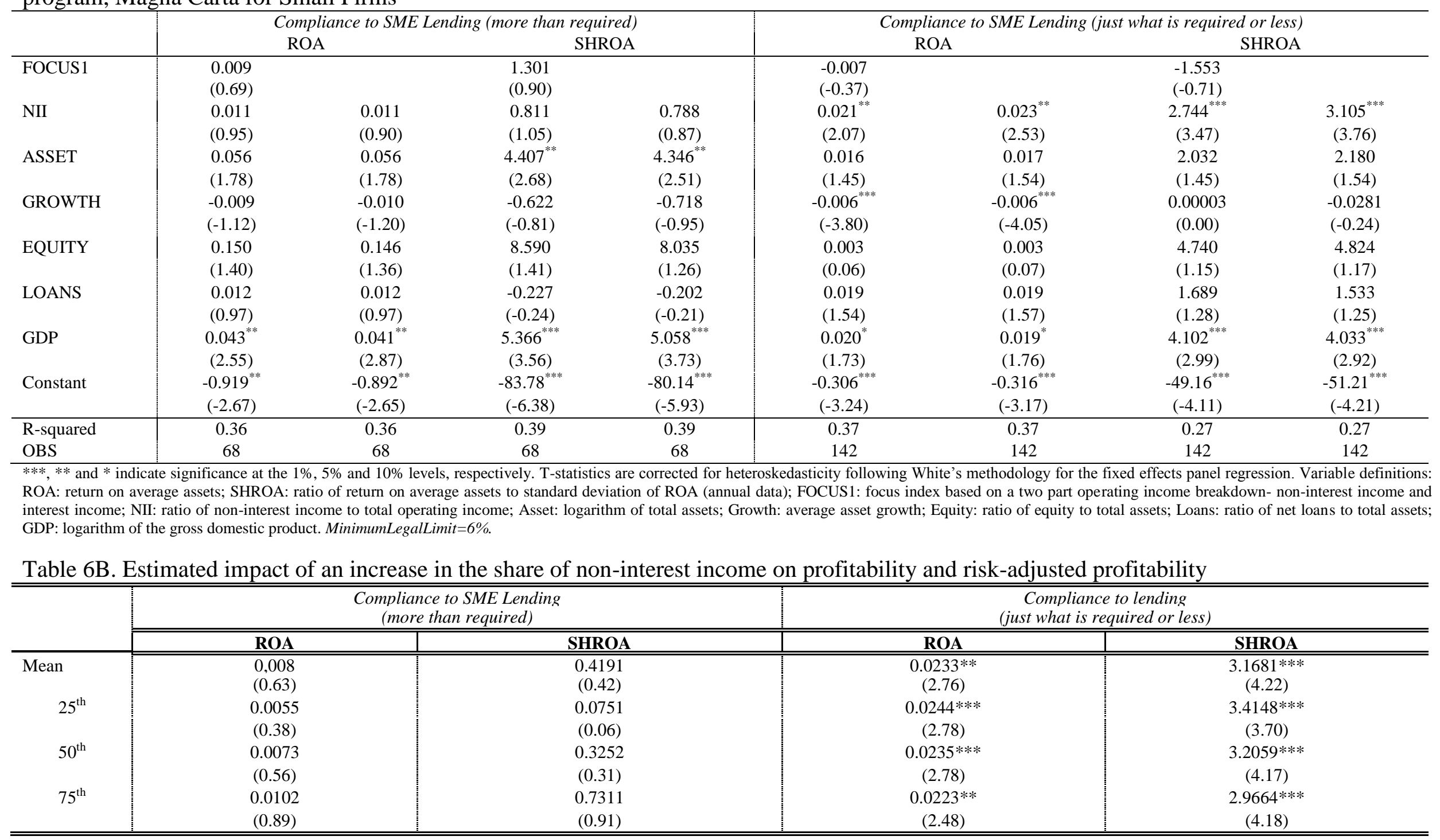


Table 7. Income diversification and profitability/risk for Philippine listed banks over the 1999-2005 period (H1)

\begin{tabular}{|c|c|c|c|c|c|c|c|c|c|c|c|c|}
\hline & \multicolumn{6}{|c|}{ LISTED BANKS } & \multicolumn{6}{|c|}{ UNIVERSAL LISTED BANKS } \\
\hline & ROA & SHROA & Beta & RiskSpec & TotRisk & $\mathrm{MZ}$ & ROA & SHROA & Beta & RiskSpec & TotRisk & MZ \\
\hline \multirow[t]{2}{*}{ FOCUS1 } & -0.009 & -1.628 & 0.0002 & 0.049 & 0.049 & $-104.8^{*}$ & -0.004 & -0.413 & -0.0001 & 0.007 & 0.006 & -65.97 \\
\hline & $(-0.98)$ & $(-1.09)$ & $(0.14)$ & $(0.61)$ & $(0.60)$ & $(-1.97)$ & $(-0.41)$ & $(-0.23)$ & $(-0.17)$ & $(0.38)$ & $(0.34)$ & $(-1.22)$ \\
\hline \multirow[t]{2}{*}{ NII } & $0.015^{* *}$ & $3.029 * * *$ & -0.001 & -0.050 & -0.051 & $133.1 * *$ & $0.023 * * *$ & $4.086 * * *$ & $-0.0006 * *$ & $-0.036 * * *$ & $-0.037 * * *$ & $137.1 * *$ \\
\hline & $(2.75)$ & (3.77) & $(-1.30)$ & $(-0.77)$ & $(-0.77)$ & $(2.38)$ & $(4.35)$ & (4.49) & $(-2.41)$ & $(-3.92)$ & $(-4.00)$ & (3.10) \\
\hline \multirow[t]{2}{*}{ ASSET } & 0.002 & 0.539 & 0.001 & 0.022 & 0.023 & 36.37 & -0.0144 & -1.987 & 0.0005 & 0.004 & 0.004 & -29.05 \\
\hline & $(0.15)$ & $(0.29)$ & $(0.69)$ & $(0.21)$ & $(0.22)$ & $(0.44)$ & $(-0.97)$ & $(-1.13)$ & (1.18) & $(0.44)$ & $(0.50)$ & $(-0.68)$ \\
\hline \multirow[t]{2}{*}{ GROWTH } & 0.003 & 0.142 & -0.001 & -0.058 & -0.059 & 0.758 & -0.0001 & 0.0467 & -0.00003 & $-0.007 * *$ & $-0.007 * *$ & $14.52 *$ \\
\hline & $(0.93)$ & $(0.28)$ & $(-1.18)$ & $(-1.21)$ & $(-1.21)$ & $(0.04)$ & $(-0.02)$ & $(0.05)$ & $(-0.78)$ & $(-2.39)$ & $(-2.32)$ & $(2.21)$ \\
\hline \multirow[t]{2}{*}{ EQUITY } & 0.032 & 8.077 & $-0.010^{* *}$ & $-0.773 * *$ & $-0.779 * *$ & -331.4 & 0.040 & 3.486 & $0.004 *$ & $0.240 * *$ & $0.244 * *$ & $-375.4 *$ \\
\hline & (1.17) & (1.49) & $(-2.19)$ & $(-2.55)$ & $(-2.54)$ & $(-1.58)$ & $(0.84)$ & $(0.35)$ & (1.94) & (2.32) & $(2.34)$ & $(-2.20)$ \\
\hline \multirow[t]{2}{*}{ LOANS } & -0.007 & -0.976 & -0.0001 & 0.006 & 0.006 & 20.15 & -0.031 & $-3.850 * *$ & -0.0005 & -0.018 & -0.018 & -78.95 \\
\hline & $(-0.46)$ & $(-0.59)$ & $(-0.12)$ & $(0.10)$ & $(0.10)$ & $(0.20)$ & $(-1.67)$ & $(-2.71)$ & $(-1.23)$ & $(-0.95)$ & $(-0.91)$ & $(-0.91)$ \\
\hline \multirow[t]{2}{*}{ GDP } & $0.024 * *$ & $5.849 * * *$ & -0.002 & -0.141 & -0.143 & 125.3 & $0.042 * * *$ & $8.686 * * *$ & -0.0001 & -0.024 & -0.025 & 81.37 \\
\hline & $(2.40)$ & $(3.06)$ & $(-0.94)$ & $(-1.22)$ & $(-1.23)$ & $(1.60)$ & (3.74) & $(7.70)$ & $(-0.69)$ & $(-1.17)$ & $(-1.20)$ & (1.74) \\
\hline \multirow[t]{2}{*}{ Constant } & $-0.180^{*}$ & $-44.7 * * *$ & 0.003 & 0.870 & 0.873 & -1160.9 & -0.119 & -35.05 & -0.005 & 0.132 & 0.129 & -106.7 \\
\hline & $(-2.06)$ & $(-3.40)$ & $(0.49)$ & $(1.33)$ & $(1.32)$ & $(-0.95)$ & $(-0.87)$ & $(-1.78)$ & $(-1.01)$ & $(0.93)$ & $(0.90)$ & $(-0.30)$ \\
\hline R-square & 0.18 & 0.28 & 0.20 & 0.19 & 0.19 & 0.22 & 0.29 & 0.37 & 0.17 & 0.41 & 0.41 & 0.28 \\
\hline OBS & 99 & 99 & 86 & 86 & 86 & 74 & 72 & 72 & 64 & 64 & 64 & 60 \\
\hline Wald Test & $4.64 * *$ & $9.69 * * *$ & 1.62 & .31 & .32 & $3.65^{*}$ & $14.94 * * *$ & $10.53 * * *$ & $3.58 *$ & $10.16^{* * *}$ & $10.15^{* * *}$ & $4.83 * *$ \\
\hline Partial & & & & & & & & & & & & \\
\hline $\begin{array}{l}\text { Effect of } \\
\text { NII on }\end{array}$ & $0.019 * *$ & $3.78 * * *$ & -0.001 & -0.072 & -0.073 & $180.7 * *$ & $0.024 * *$ & $4.28 * *$ & -0.001 & $-0.039 * *$ & $-0.04 * *$ & $163.02 * *$ \\
\hline $\begin{array}{l}\text { Nil on } \\
\text { Perf }\end{array}$ & $0.019 \cdots$ & $3.18 \cdots$ & -0.001 & $-0.0 / 2$ & $-0.0 / 3$ & $180.1 \times$ & $0.0 \angle 4 \cdots$ & $4.28 \cdots$ & -0.001 & $-0.039 \cdots$ & $-0.04 \cdots$ & $103.02 \mathrm{~F}$ \\
\hline
\end{tabular}


Table 8. Product mixes within non-interest activities and profitability/risk for Philippine listed banks over the 1999-2005 period (H2, model 2a)

\begin{tabular}{|c|c|c|c|c|c|c|c|c|c|c|c|c|}
\hline & \multicolumn{6}{|c|}{ LISTED BANKS } & \multicolumn{6}{|c|}{ UNIVERSAL LISTED BANKS } \\
\hline & ROA & SHROA & Beta & RiskSpec & TotRisk & MZ & ROA & SHROA & Beta & RiskSpec & TotRisk & $\mathrm{MZ}$ \\
\hline \multirow[t]{2}{*}{ FOCUS2 } & -0.015 & -1.458 & 0.001 & 0.151 & 0.152 & -87.89 & -0.006 & 1.877 & 0.0001 & 0.021 & 0.020 & -28.41 \\
\hline & $(-1.16)$ & $(-0.62)$ & $(0.56)$ & $(1.23)$ & $(1.22)$ & $(-0.87)$ & $(-0.21)$ & $(0.58)$ & $(0.25)$ & $(0.99)$ & $(0.95)$ & $(-0.47)$ \\
\hline \multirow[t]{2}{*}{ FEE } & 0.016 & -3.390 & 0.002 & 0.179 & 0.180 & -47.85 & 0.025 & -1.702 & -0.0004 & -0.022 & -0.023 & -39.91 \\
\hline & $(0.34)$ & $(-0.52)$ & $(0.80)$ & $(0.78)$ & $(0.78)$ & $(-0.38)$ & $(0.77)$ & $(-0.38)$ & $(-0.61)$ & $(-1.05)$ & $(-1.10)$ & $(-0.56)$ \\
\hline \multirow[t]{2}{*}{ TRAD } & 0.012 & 2.922 & $-0.001 *$ & -0.006 & -0.007 & 110.0 & $0.025 * * *$ & $6.215 * * *$ & $-0.001 * * *$ & $-0.032 * * *$ & $-0.034 * * *$ & $153.9^{* *}$ \\
\hline & (1.62) & $(1.71)$ & $(-1.87)$ & $(-0.11)$ & $(-0.12)$ & $(1.22)$ & (3.38) & $(5.53)$ & $(-5.33)$ & $(-3.79)$ & $(-3.92)$ & $(2.39)$ \\
\hline \multirow[t]{2}{*}{ Other } & -0.027 & -2.098 & 0.0006 & 0.104 & 0.104 & 34.00 & -0.003 & 3.606 & -0.0001 & 0.006 & 0.004 & 81.28 \\
\hline & $(-0.69)$ & $(-0.42)$ & $(0.61)$ & (1.61) & (1.59) & $(0.35)$ & $(-0.06)$ & $(0.89)$ & $(-0.23)$ & $(0.23)$ & $(0.17)$ & $(0.93)$ \\
\hline \multirow[t]{2}{*}{ ASSET } & 0.004 & 0.777 & 0.001 & 0.032 & 0.033 & 38.14 & -0.014 & -2.140 & 0.0006 & -0.001 & -0.0003 & -30.98 \\
\hline & $(0.33)$ & $(0.39)$ & $(0.72)$ & $(0.26)$ & $(0.27)$ & $(0.44)$ & $(-0.86)$ & $(-1.04)$ & (1.18) & $(-0.12)$ & $(-0.02)$ & $(-0.61)$ \\
\hline \multirow[t]{2}{*}{ GROWTH } & 0.002 & -0.103 & -0.001 & -0.054 & -0.054 & -1.371 & -0.00002 & -0.120 & -0.00003 & -0.006 & -0.006 & 9.590 \\
\hline & $(0.64)$ & $(-0.19)$ & $(-1.17)$ & $(-1.22)$ & $(-1.22)$ & $(-0.07)$ & $(-0.00)$ & $(-0.12)$ & $(-0.68)$ & $(-1.67)$ & $(-1.63)$ & (1.46) \\
\hline \multirow[t]{2}{*}{ EQUITY } & 0.019 & 5.647 & $-0.009 * *$ & $-0.736^{* *}$ & $-0.742 * *$ & $-376.6^{*}$ & 0.038 & 4.572 & 0.004 & $0.234 * *$ & $0.237 * *$ & $-406.7 * *$ \\
\hline & $(0.66)$ & (1.10) & $(-2.15)$ & $(-2.54)$ & $(-2.53)$ & $(-1.76)$ & $(0.71)$ & $(0.50)$ & $(1.80)$ & $(2.34)$ & $(2.36)$ & $(-2.63)$ \\
\hline \multirow[t]{2}{*}{ LOANS } & -0.006 & -1.260 & 0.00002 & 0.007 & 0.007 & 30.02 & $-0.034 * *$ & $-4.898 * * *$ & -0.0004 & -0.021 & -0.020 & -86.00 \\
\hline & $(-0.52)$ & $(-0.69)$ & $(0.02)$ & $(0.11)$ & $(0.12)$ & $(0.28)$ & $(-2.47)$ & $(-4.57)$ & $(-1.01)$ & $(-1.08)$ & $(-1.01)$ & $(-0.99)$ \\
\hline \multirow[t]{2}{*}{ GDP } & $0.026^{*}$ & $5.379 * *$ & -0.002 & -0.143 & -0.145 & 106.1 & $0.046^{* *}$ & $8.394 * * *$ & -0.0002 & -0.020 & -0.021 & 65.58 \\
\hline & $(1.96)$ & $(2.54)$ & $(-0.87)$ & $(-1.17)$ & $(-1.17)$ & $(1.74)$ & (2.97) & $(4.82)$ & $(-0.83)$ & $(-1.00)$ & $(-1.04)$ & $(1.62)$ \\
\hline \multirow[t]{2}{*}{ Constant } & $-0.21 * *$ & $-42.64 * * *$ & -0.001 & 0.679 & 0.679 & -1028.9 & -0.142 & -31.76 & -0.005 & 0.148 & 0.144 & 33.17 \\
\hline & $(-2.21)$ & $(-3.01)$ & $(-0.10)$ & $(0.89)$ & $(0.89)$ & $(-0.83)$ & $(-0.97)$ & $(-1.50)$ & $(-0.94)$ & (1.13) & $(1.08)$ & (0.09) \\
\hline R-square & 0.24 & 0.37 & 0.23 & 0.21 & 0.21 & 0.22 & 0.35 & 0.48 & 0.20 & 0.44 & 0.437 & 0.317 \\
\hline OBS & 96 & 96 & 84 & 84 & 84 & 72 & 70 & 70 & 62 & 62 & 62 & 58 \\
\hline Wald Test & $4.36 * *$ & $9.03 * * *$ & 1.86 & 1.96 & 1.94 & $3.01 *$ & $39.13 * * *$ & $15.96 * * *$ & $9.68 * * *$ & $23.98 * * *$ & $24.26 * * *$ & $13.71 * * *$ \\
\hline $\begin{array}{l}\text { Partial Effect } \\
\text { on Perf: }\end{array}$ & & & & & & & & & & & & \\
\hline FEE & 0.013 & -3.72 & 0.003 & 0.212 & 0.214 & -69.25 & 0.023 & -1.24 & -0.000 & -0.017 & -0.018 & -46.94 \\
\hline TRAD & 0.01 & 2.35 & -0.001 & 0.053 & 0.053 & 74.33 & $0.024 *$ & $6.90 * * *$ & $-0.001 * *$ & -0.025 & $-0.027^{*}$ & 143.76 \\
\hline Other & -0.03 & -2.32 & 0.001 & 0.128 & 0.128 & 19.20 & -0.004 & 3.92 & -0.00 & 0.009 & 0.008 & 76.54 \\
\hline
\end{tabular}

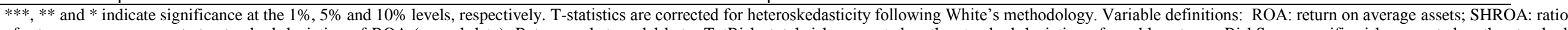

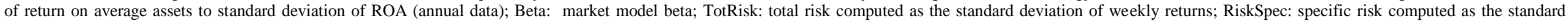

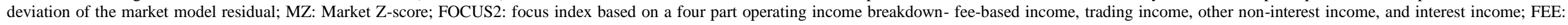

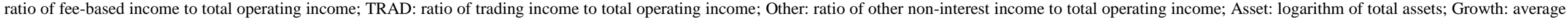
asset growth; Equity: equity to total assets; Loans: ratio of net loans to total assets; GDP: logarithm of the gross domestic product. 